\title{
Somatic Signature of Brain-Specific Single Nucleotide Variations in Sporadic Alzheimer's Disease
}

\author{
Antoni Parcerisas ${ }^{\mathrm{a}, \mathrm{b}}$, Sara E. Rubio ${ }^{\mathrm{a}, \mathrm{b}}$, Ashraf Muhaisen ${ }^{\mathrm{a}, \mathrm{b}}$, Alberto Gómez-Ramos ${ }^{\mathrm{b}, \mathrm{c}}$, Lluís Pujadas ${ }^{\mathrm{a}, \mathrm{b}}$, \\ Montserrat Puiggros $^{\mathrm{d}}$, Daniela Rossi ${ }^{\mathrm{a}, \mathrm{b}}$, Jesús Ureña $\mathrm{a}^{\mathrm{a}, \mathrm{b}}$, Ferrán Burgaya ${ }^{\mathrm{a}, \mathrm{b}}$, Marta Pascual ${ }^{\mathrm{a}, \mathrm{b}}$, \\ David Torrents $^{\mathrm{a}, \mathrm{e}}$, Alberto Rábano ${ }^{\mathrm{f}}$, Jesús Ávila ${ }^{\mathrm{b}, \mathrm{c}, 1, *}$ and Eduardo Soriano ${ }^{\mathrm{a}, \mathrm{b}, \mathrm{f}, \mathrm{g}, 1, *}$ \\ ${ }^{a}$ Department of Cell Biology, University of Barcelona, Barcelona, Spain \\ ${ }^{\mathrm{b}}$ Centro de Investigación Biomédica en Red sobre Enfermedades Neurodegenerativas (CIBERNED, ISCIII), Spain \\ ${ }^{\mathrm{c} C e n t r o ~ d e ~ B i o l o g i ́ a ~ M o l e c u l a r ~ S e v e r o ~ O c h o a ~(C S I C-U A M), ~ M a d r i d, ~ S p a i n ~}$ \\ $\mathrm{d}$ Joint IRB-BSC Program in Computational Biology, Barcelona Supercomputing Center, Barcelona, Spain \\ e Institució Catalana de Recerca i Estudis Avançats (ICREA), Barcelona, Spain \\ ${ }^{\mathrm{f}}$ Fundación CIEN, Vallecas, Madrid, Spain \\ ${ }^{\mathrm{g}}$ Vall d'Hebrón Institut de Recerca (VHIR), Barcelona, Spain
}

Accepted 14 May 2014

\begin{abstract}
.
Background: Although genome-wide association studies have shown that genetic factors increase the risk of suffering late-onset, sporadic Alzheimer's disease (SAD), the molecular mechanisms responsible remain largely unknown.

Objective: The aim of the study was to investigate the presence of somatic, brain-specific single nucleotide variations (SNV) in the hippocampus of SAD samples.

Methods: By using bioinformatic tools, we compared whole exome sequences in paired blood and hippocampal genomic DNAs from 17 SAD patients and from 2 controls and 2 vascular dementia patients.

Results: We found a remarkable number of SNVs in SAD brains ( $~ 575$ per patient) that were not detected in blood. Loci with hippocampus-specific (hs)-SNVs were common to several patients, with 38 genes being present in 6 or more patients out of the 17. While some of these SNVs were in genes previously related to SAD (e.g., CSMD1, LRP2), most hs-SNVs occurred in loci previously unrelated to SAD. The most frequent genes with hs-SNVs were associated with neurotransmission, DNA metabolism, neuronal transport, and muscular function. Interestingly, 19 recurrent hs-SNVs were common to 3 SAD patients. Repetitive loci or hs-SNVs were underrepresented in the hippocampus of control or vascular dementia donors, or in the cerebellum of SAD patients.

Conclusion: Our data suggest that adult blood and brain have different DNA genomic variations, and that somatic genetic mosaicism and brain-specific genome reshaping may contribute to SAD pathogenesis and cognitive differences between individuals.
\end{abstract}

Keywords: Alzheimer's disease, exome sequencing, somatic variations

\footnotetext{
${ }^{1}$ The senior authors contributed equally to this study.

*Correspondence to: Dr. Eduardo Soriano, Department of Cell Biology, University of Barcelona, Barcelona E-08028, Spain. Tel.: +3493 4037117; E-mail: esoriano@ub.edu and Dr. Jesús Ávila, Centro de Biología Molecular Severo Ochoa (CSIC-UAM), Madrid E-28049, Spain. Tel.: +34 91 1964564; E-mail: javila@cbm.uam.es.
} 


\section{INTRODUCTION}

Alzheimer's disease (AD) is classified into two types: familial AD (FAD), predominantly associated with early onset, and sporadic AD (SAD) associated with late onset. Genomic analyses have shown that FAD is caused by mutations in amyloid- $\beta$ protein precursor (A $\beta P P)$, presenilin 1 (PSEN1), and presenilin 2 (PSEN2) genes, and by duplications in the A $\beta P P$ gene [1-4]. In contrast, the mechanisms that trigger SAD are largely unknown, although various risk factors have been established, including vascular disease (VaD), elevated cholesterol levels, and obesity/diabetes [3, 5, 6]. Neuropathological hallmarks for SAD include amyloid- $\beta$ (A $\beta$ ) pathology and aggregation, and tau phosphorylation [2, 7]. Moreover, the APOE4 allele is strongly associated with $\operatorname{SAD}[8,9]$. Large-scale genome-wide association studies (GWAS) have identified several additional loci, including CLU, PICALM, CR1, BIN1, ABCA7, EPHA1, TREM2, CD33, PTK2B, and INPP5D as genetic risk factors for SAD [10-19].

Some diseases, particularly cancer, are associated with somatic genomic events, which occur in only one generation or one group of cells and which may affect specific genes. Approximately $80 \%$ of cancers arise from somatic mutations [20, 21]. It is generally held that the initial step in many tumors is mediated by DNA damage and mutations, which trigger activation of proto-oncogenes, the inactivation of tumor-suppressor genes, and ultimately tumor progression and metastasis. The identification of genes that are mutated in cancer has been critical not only for our understanding of the pathogenesis, but also for the design of novel therapeutic tools [22, 23].

To our knowledge, systematic studies for the search of somatic brain mutations in SAD or other neurological diseases have not been performed so far. Here we use whole-exome sequencing to investigate the presence of single-nucleotide polymorphisms (SNPs), single nucleotide variations (SNVs), and mutations (all referred to here as SNVs) that are specific to brain genomic DNA in SAD, and which are not present in the blood genome of the same donors. We found a striking number of brain-specific SNVs in SAD patients. Together with recent studies reporting brainspecific retrotrasposon insertions $[24,25]$ and somatic copy number variations (CNVs) in control human neurons [26], our results highlight variability in the brain genome, and suggest that genetic mosaicism and brain-specific genetic variations may contribute to the pathogenesis of SAD.

\section{MATERIALS AND METHODS}

\section{Brain tissue processing and characterization}

Shortly after the death of the donor, the whole brain was obtained through a neuropathological autopsy and divided into two symmetrical halves through a midsagittal section. Thereafter, the right half was immediately cut in coronal (hemisphere), sagittal (cerebellum), or transversal (brainstem) slices. Each tissue slice was individually frozen by immersion in $-50^{\circ} \mathrm{C}$ isopentane (Shandon Histobath ${ }^{\mathrm{TM}} 2$ ) and transferred to a $-80^{\circ} \mathrm{C}$ freezer for long-term storage. The left brain half was fixed in $4 \%$ buffered formaldehyde and sectioned. Multiple tissue blocks were obtained from cortical and subcortical regions and processed for paraffin sectioning and hematoxylin-eosin staining. Additionally, a battery of immunostaining detections was performed on selected sections, and a neuropathological diagnosis and classification of cases was obtained according to well-established consensus criteria. Classification and staging of Alzheimer-type pathology was based on density and score of neuritic plaques according to CERAD criteria, and Braak's staging of neurofibrillary pathology. Frozen tissue samples of hippocampus and cerebellum were taken from previously frozen tissue slices. The hippocampus was dissected with the aid of a stereomicroscope so as to obtain samples limited to CA1-CA3 sectors of the hippocampal cortex. Samples of the cerebellum corresponded to lateral hemispheric foliae. Blood samples were obtained simultaneously with routine blood extractions for laboratory evaluation of patients.

Genomic DNA was extracted from brain tissue samples and from the blood of donors who had been clinically and neuropathologically confirmed as SAD. Brain tissue and blood samples were obtained from two Spanish brain banks (Banco de Tejidos CIEN [BTCIEN] and Banco de Cerebros de la Región de Murcia [BCRM]) working with similar processing protocols, approved by their respective ethical committees. Samples from two control donors (with no neurological and neuropathological signs) and from two donors clinically and neuropathologically diagnosed as $\mathrm{VaD}$, were also included in the study. DNA was extracted using Qiagen kits.

\section{Sample processing for exome sequencing}

Three $\mu \mathrm{g}$ of genomic DNA (from blood, hippocampus, and cerebellum) was fragmented to an average size of 200 bp using a Covaris LE220 instrument. Short 
insert libraries were obtained with Illumina's TruSeq DNA Sample Preparation Kit. Exonic sequences were enriched using NimbleGen's Sequence Capture Human Exome 2.1M Array. Paired-end sequences of 91 nucleotides from each end were generated using an Illumina's HiSeq 2000 instrument to an average of 50x coverage. Sequences were generated in fastaq format.

\section{Sequencing quality control}

All samples passed quality filters after sequencing according to the following criteria: 1) Reads with ambiguous bases (represented by letter $\mathrm{N}$ ) more than $5 \%$ of bases or poly-A structure constituents; 2) Reads that have 20 bases with quality score less than or equal to 7 for the library were filtered. 3) Reads with adapter contamination: reads with more than $10 \mathrm{bp}$ aligned to the adapter sequence (no more than $3 \mathrm{bp}$ mismatch allowed); 4) Small insert-size reads in which read 1 and read 2 overlapped by 10 bp or more $(10 \%$ mismatch allowed); 5) PCR duplications (reads are considered duplications when read 1 and read 2 of the same paired end reads are identical). Individual reads not passing any one of these filters were discarded from the analysis. Furthermore, overall quality was controlled with the fastqc software (http://www. bioinformatics.bbsrc.ac.uk/projects/fastqc) ensuring that all samples passed checks with default parameters.

\section{Mapping and initial base calling}

Samples were aligned to the human reference genome version hg19 [27] using the BWA aligner software [28] with default parameters. For each patient, brain and blood samples were preprocessed by removing duplicate reads [29] using Picard (http:// picard.sourceforge.net/index.shtml). Samples from the same patients were merged using SAMtools and preprocessed before base calling. Local realignment was performed around INDELs to improve SNP calling in these conflictive areas (IndelRealigner from [30]). After merging patient samples to avoid recalibration biases to affect samples independently, base quality scores were recalibrated using the baseRecalibrator tool from the Genome Analyzer Toolkit [30]. Once recalibrated, samples were split by tissue with BAMtools [31]. The UnifiedGenotyper algorithm from [30] was then used with default parameters (see [32] and [33] for details) to call SNPs in the merged file. For each of the variants called which had a read depth $\geq 25$ reads in both tissues, we performed a Fisher test on the observed number of reads with the alternative allele in each sample. Candidate SNVs with a $p$-value larger than 0.05 were discarded. Finally, variants were annotated using the dbSNP database version 132 [34], the UCSC human RefGene [35], and the software snpEFF [36] (see Supplementary Methods).

\section{Tissue-specific SNV discovery}

The routine UnifiedGenotyper from GATK was used to call candidate SNVs in each tissue sample. These SNVs were filtered with parameters recommended in Best Practices of the GATK website (http://www.broadinstitute.org/gatk/), with the exception of the quality of the SNV call (QUAL) which was lowered to 20 to allow for more candidates when comparing tissues. SNPs were annotated using snpEff2.0.5 [37] and GATK's SNPannotator. In order to find SNVs specific to the hippocampus, we compared the number of reads for the reference and alternative alleles in each candidate position for both samples. A Fisher test was performed comparing the number of reads of the reference allele and the most frequent alternate allele in each sample. We declared as blood/brain specific SNVs those SNVs whose Fisher's test $p$-value was lower than 0.05 and whose read depth was $\geq 25$ for both samples. Tissue-specific SNVs were considered as hippocampus-specific SNVs (hs-SNVs), bloodspecific (bs-SNVs), or cerebellum-specific (cs-SNVs) considering the tissue which contains the alternative allele or its higher percentage.

\section{Further statistics calculations}

Further statistics were calculated as follows: dbSNP coverage was calculated against dbSNP version 132 [34]. Exonic SNPs were found using annotations from UCSC version hg19 [35].

\section{RESULTS}

\section{Exome sequencing and genotyping of blood and hippocampi reveal brain-specific SNVs}

To test the hypothesis that somatic variations and mutations may contribute to the genetic component of $\mathrm{SAD}$, we sequenced the exomes of 17 clinically and neuropathologically confirmed SAD patients, comparing genomic DNA from blood and hippocampi from the same donors (Supplementary Table 1). Briefly, we enriched exonic sequences from genomic DNA using the NimbleGen's Sequence Capture Human Exome 2.1 M Array and performed Illumina's HiSeq 
2000 paired-end sequencing (Fig. 1a). On average, we obtained $6.2 \mathrm{~Gb}$ of mappable sequence data per individual after exome enrichment, targeting 37 megabases $(\mathrm{Mb})$ from exons and their flanking regions. Overall, we covered $1.22 \%$ of the genome, a fraction corresponding closely to the NCBI Consensus Coding Sequences database (CCDS). Quality controls using the fastaQC program were applied to reads from each sample and showed high per base and per sequence quality, even G/C content along reads and no overrepresented or high Kmer content.

We aligned reads from each sample independently to the human reference genome [27] using the BurrowsWheeler Aligner [28]. An average of $99.1 \%$ of the reads aligned correctly with the genome. The mean read depth in targeted regions was 60.8 reads. In addition, $79.4 \%$ of the captured exonic regions were covered with at least 25 reads.

In order to identify genomic variations we applied various processing and genotyping tools. Briefly, we removed duplicated reads from individual samples [29]. In the first step, we used the GATK software for calling SNVs in blood and brain samples [30,32]. To this end we merged samples from both tissues for each patient and realigned reads around problematic areas with indels (indel realigner). We then recalibrated read qualities (quality recalibration) and split the data into blood and hippocampus reads. We applied the UnifiedGenotyper (from the GATK package) to find SNVs using the default parameters. We filtered SNVs as described [33] with the exception of higher calling quality (QUAL <25). We also filtered out the SNVs found in duplicated regions in the human genome annotated in the UCSC database [38, 39] with a segmental duplication score larger than 0.8 .

Once the positions of the SNVs were known, we calculated the distance between samples based on the observed proportion of the four bases in all SNVs from all samples. As expected, paired samples cluster together. A heatmap is presented in Fig. 1b showing that the distance between paired samples is much lower than the distance to any other sample.

In order to identify hs-SNVs, we compared the SNVs from hippocampus with the corresponding genomic positions in blood. We selected positions with confident calls whose proportions of reference and alternative alleles were significantly different. SNVs with $p$-values (Fisher test) lower than 0.05 were retained. Only SNVs with a read depth $\geq 25$ were considered.

The great majority of SNVs found in the hippocampus, whether heterozygous or homozygous, had similar percentages of non-reference allele reads in the blood counterpart (Fig. 1c, right insert). Nevertheless, some positions showed very different proportions between blood and hippocampus (Fig. 1c, left), including those with a clear increase or decrease in non-reference alleles in hippocampus. We also noticed a significant number of hippocampal variations that were present with low numbers of reads with the alternative allele (usually 20-30\%), which may suggest mosaicism.

For $3 \mathrm{SAD}$ donors we sequenced samples from the cerebellum and repeated the procedures describe above for the hippocampal sequences in order to identify SNVs that were shared or unique to the cerebellum.

\section{Characterization and specificity of hs-SNVs in $S A D$}

We found an average number of 37.605 SNVs per single genomic DNA sample (Fig. 2a). Overall, a very large fraction of SNVs were annotated in dbSNP database (version 132) (94\%), which bears witness to the quality of sequencing and analysis (Fig. 2a). An average of 15,484 SNVs (41\%) were found in exonic regions, with a ts/tv ratio of $\sim 2.31$ in these regions (Fig. 2a). Although most ( $97 \%)$ of these SNVs were common to both blood and hippocampal DNA, in all patients we found a consistent number of hs-SNVs (average 577, Fig. 2b, c; Supplementary Table 2). Similarly, we also found SNVs that were specific for blood (Fig. $2 \mathrm{~b}$ and Supplementary Table 2). A large number of hs-SNVs were annotated in dbSNP ( $95 \%$, Fig. 2c). About $43 \%$ of the brain-specific variations were present in exons, with the remaining variations being located in intronic, downstream or intergenic regions (Fig. 2d).

We annotated SNVs according to their potential functional impact as defined in the annotation package snpEFF [39] (Supplementary Tables 2 and 3). Overall, $17.3 \%$ of the hs-SNVs had high to moderate impact whereas 19\% had low impact and $63.7 \%$ of hs-SNVs had modifier impact. We found a number of non-synonymous coding hs-SNVs (1661), translational start gains (25) and losses (2), stop gains (12), and losses (3) and splice site donors and acceptors (19) (Fig. 2e).

We next analyzed the chromosomal distribution of hs-SNVs. As illustrated in Fig. 3, hs-SNVs were present in all chromosomes with a regional distribution which largely paralleled the distribution of all the identified SNVs.

The loci with hs-SNVs in SAD donors are listed in Supplementary Table 4 . To discern whether these loci 
a

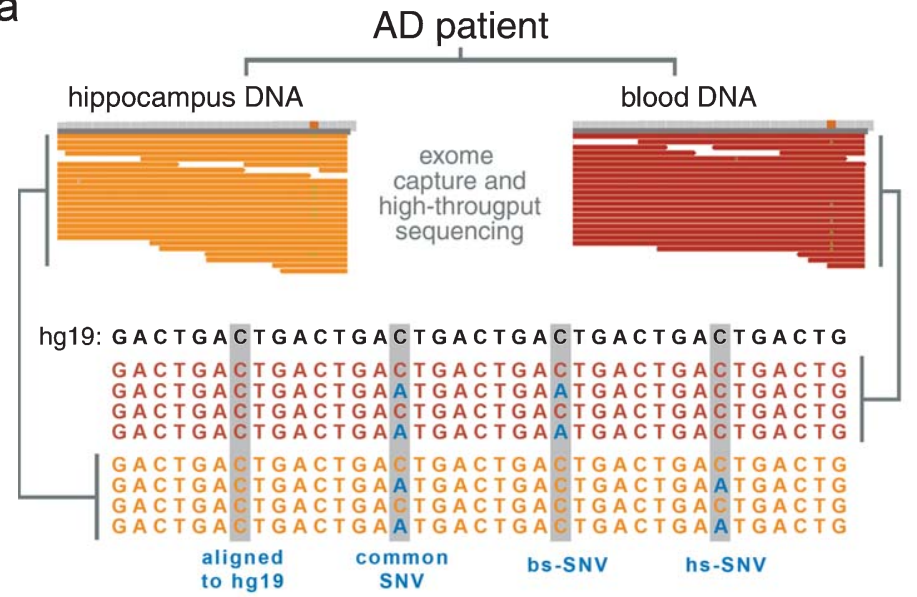

b

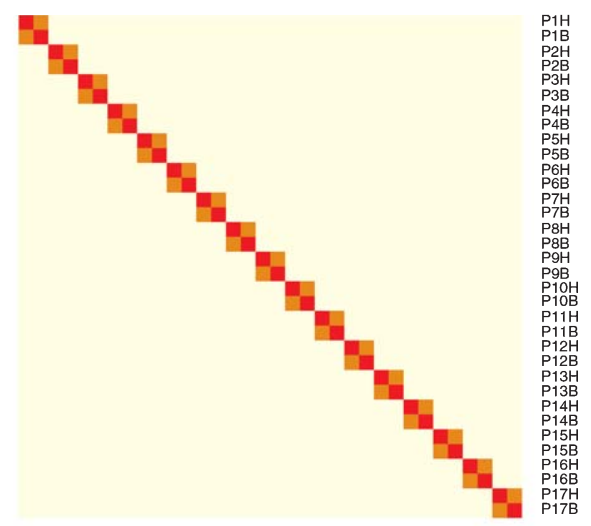

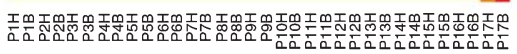

C

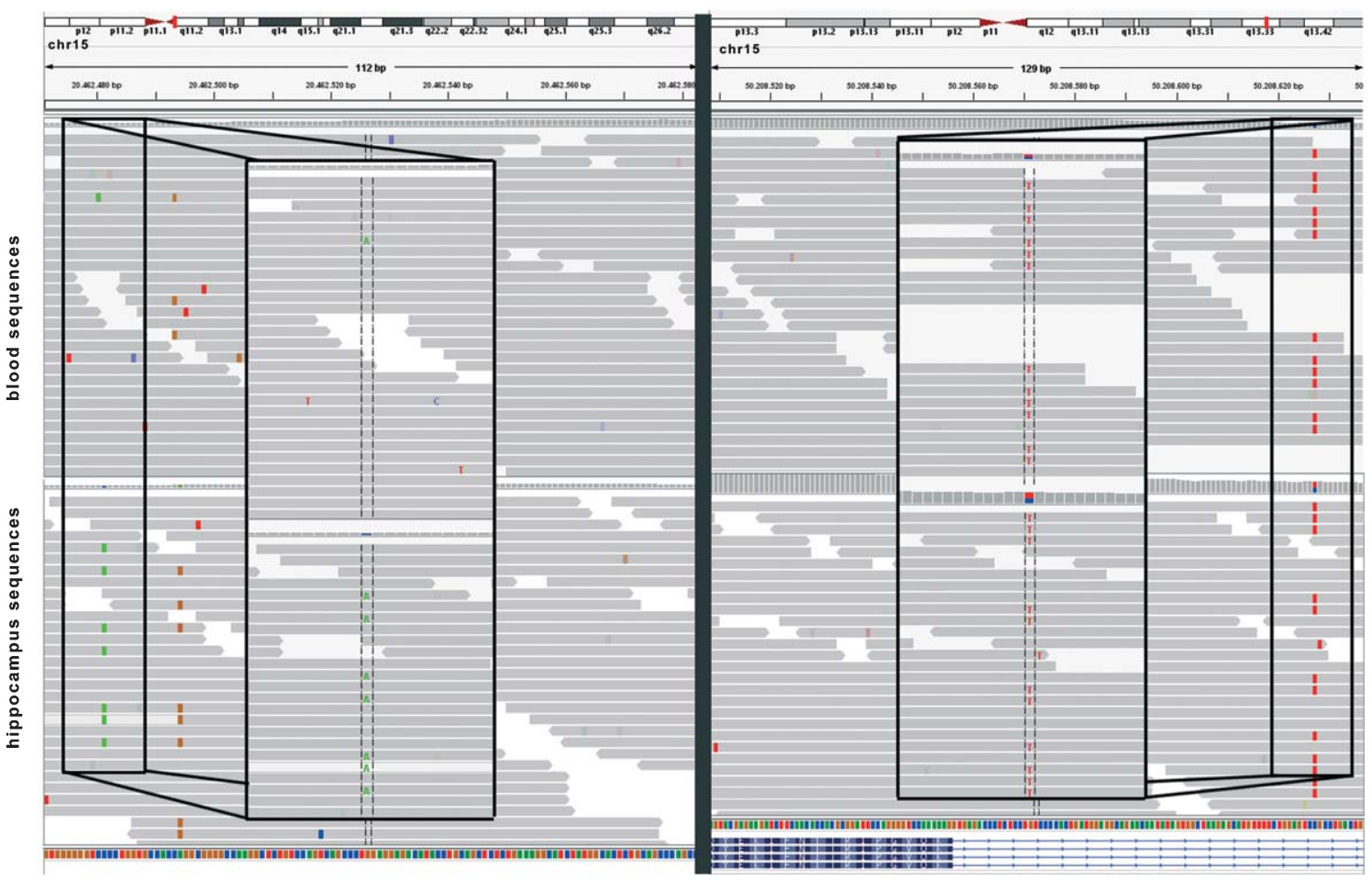

Fig. 1. a) Flow chart illustrating the experimental approach used. Blood and hippocampal genomic DNAs from the same donors were exome sequenced and blood-specific (bs) and hippocampus-specific (hs)-SNVs were identified. b) Distance heatmap demonstrating high sequence similarities between blood and brain DNAs from the same patients, and high distance between patients. c) IGV view of blood (upper) and hippocampal (below) DNA sequence in chromosome 15, illustrating one example of a variation common to blood and hippocampus (right) and a hs-SNV (left) in the ATP8B4 and RHPN2P1 loci, respectively.

were specific to SAD, we compared sequences from hippocampal and blood genomic DNAs obtained from 2 control individuals, with no neural disease, and 2 donors clinically and neuropathologically diagnosed with VaD (Supplementary Table 1). As in SAD, we detected both blood- and hs-SNVs, with numbers of hs-SNVs being similar to those in SAD (Fig. 4 a-c;
Supplementary Tables 2 and 5). We next calculated the percentage of coincident loci with SAD. About $13 \%$ and $21 \%$ of loci with hs-SNVs in control and $\mathrm{VaD}$ samples overlapped with SAD loci, respectively. Conversely, $8 \%$ and $10 \%$ of loci with hs-SNVs in SAD samples overlapped with those in control and $\mathrm{VaD}$ brain samples (Fig. 4d, e). 
a

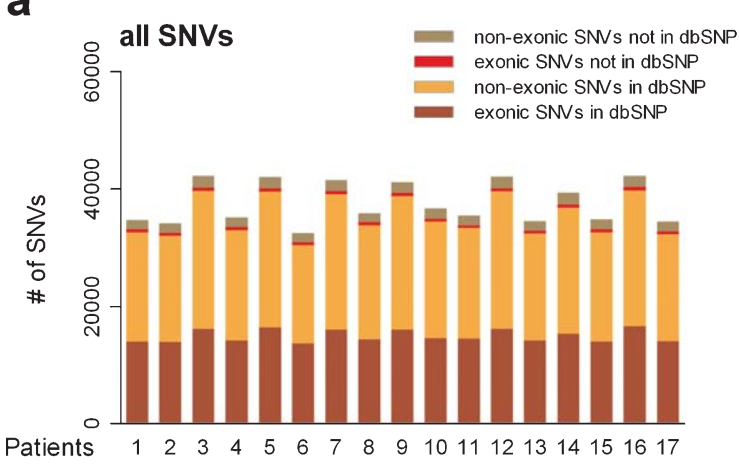

b

b all SNVs

blood specific SNVs $\square$ HP specific SNs $\square$ common SNS

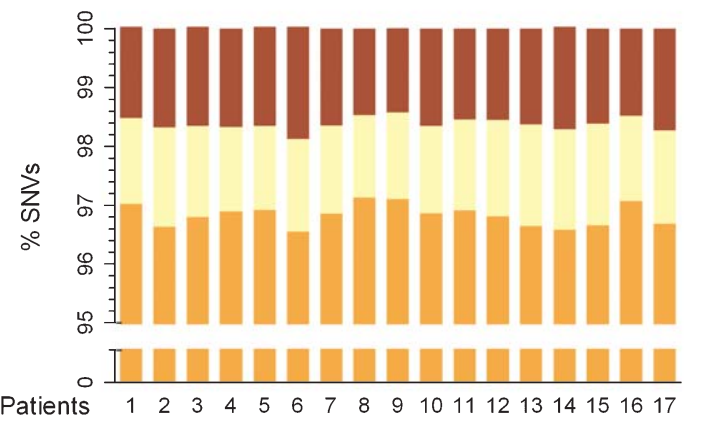

d

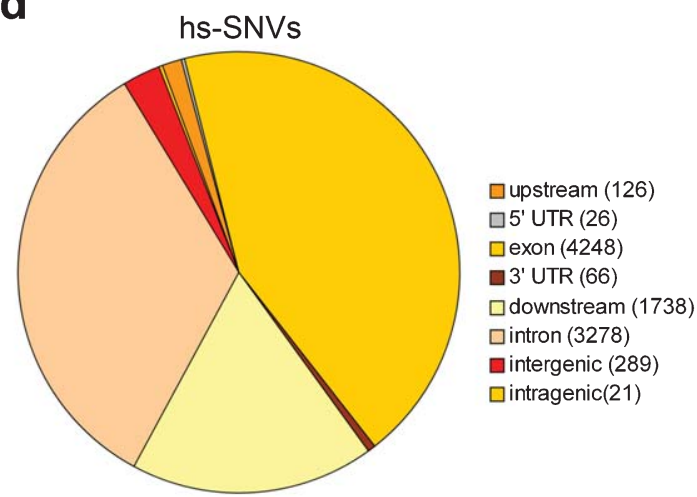

e

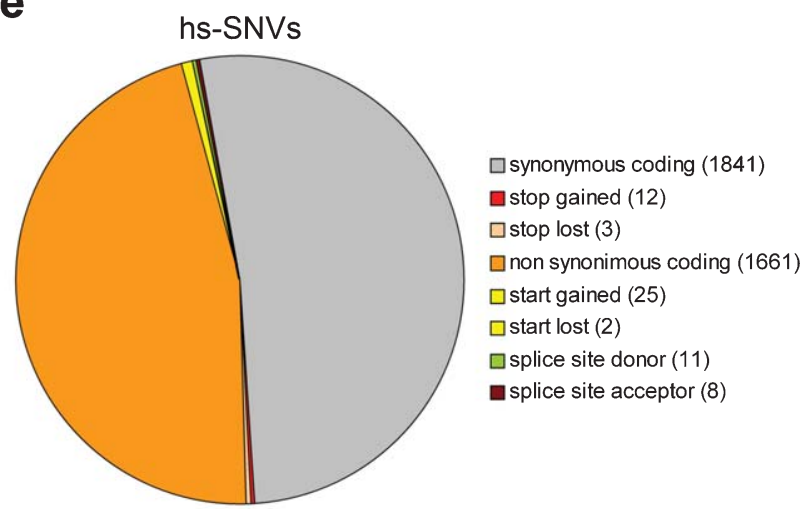

C

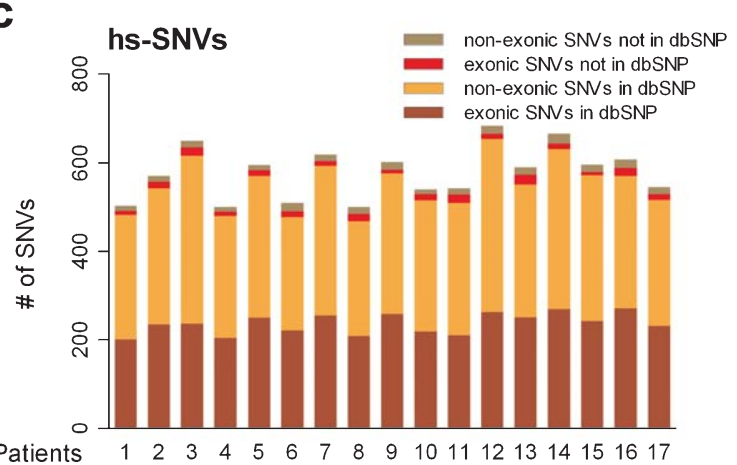

Fig. 2. Characteristics and distribution of SNVs and hs-SNVs in 17 SAD samples. a) Distribution of all (blood and hippocampus) SNVs per patient, according to their annotation in dbSNP and their location in exonic and non-exonic regions. b) Percentage of blood-specific (bs), hippocampus-specific (hs) and common SNVs per SAD patient. Note that about $97 \%$ of SNVs were common to blood and hippocampal samples, whereas about $1.5 \%$ were hippocampus-specific. c) Classification and number of hs-SNVs/patient, according to their annotation in dbSNP and their location in exonic and non-exonic regions. d) Overall distribution of hs-SNVs, according to their genetic location. e) Overall distribution of hs- SNV in $17 \mathrm{SAD}$ patients according to their functional impact.

We also screened brain-specific SNVs in the cerebella of 3 SAD patients (Fig. 4f-i; Supplementary Table 6). We found that only about $9 \%$ of brain-specific loci were common to the hippocampus and cerebellum of the same donors (Fig. 4i, Supplementary Table 7). Taken together, the data suggest that the hippocampus of SAD brains may display a specific somatic genetic signature.
Common hippocampus-specific genes in SAD: Relationship to AD pathogenesis and neurological diseases

The list of genes with hs-SNVs ordered by the number of patients with at least one mutation in the corresponding gene is shown in Supplementary Table 4. Interestingly, 2 genes (SYNE1, AC073995.2) 

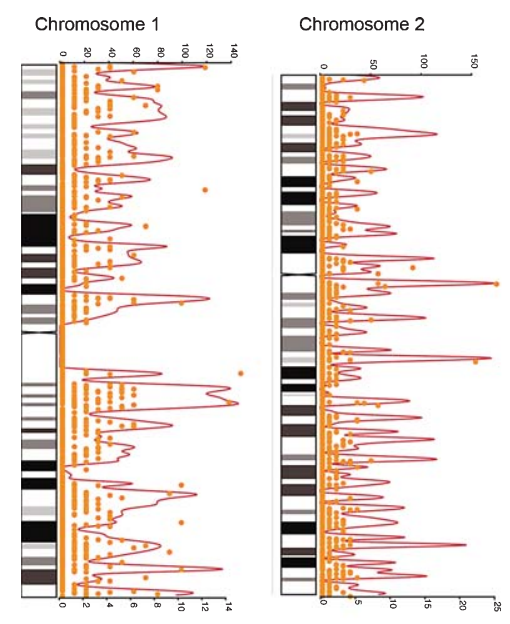

Chromosome 3

Chromosome 4

Chromosome 5

Chromosome 6

Chromosome 7
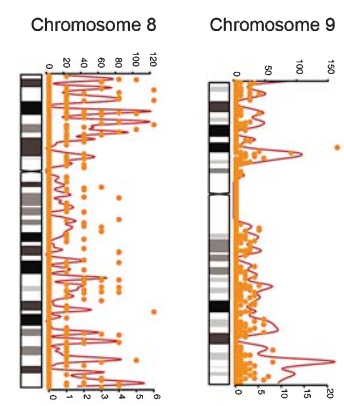

Chromosome 10

Chromosome 11

Chromosome 12

Chromosome 13

Chromosome 14

Chromosome 15

Chromosome 16
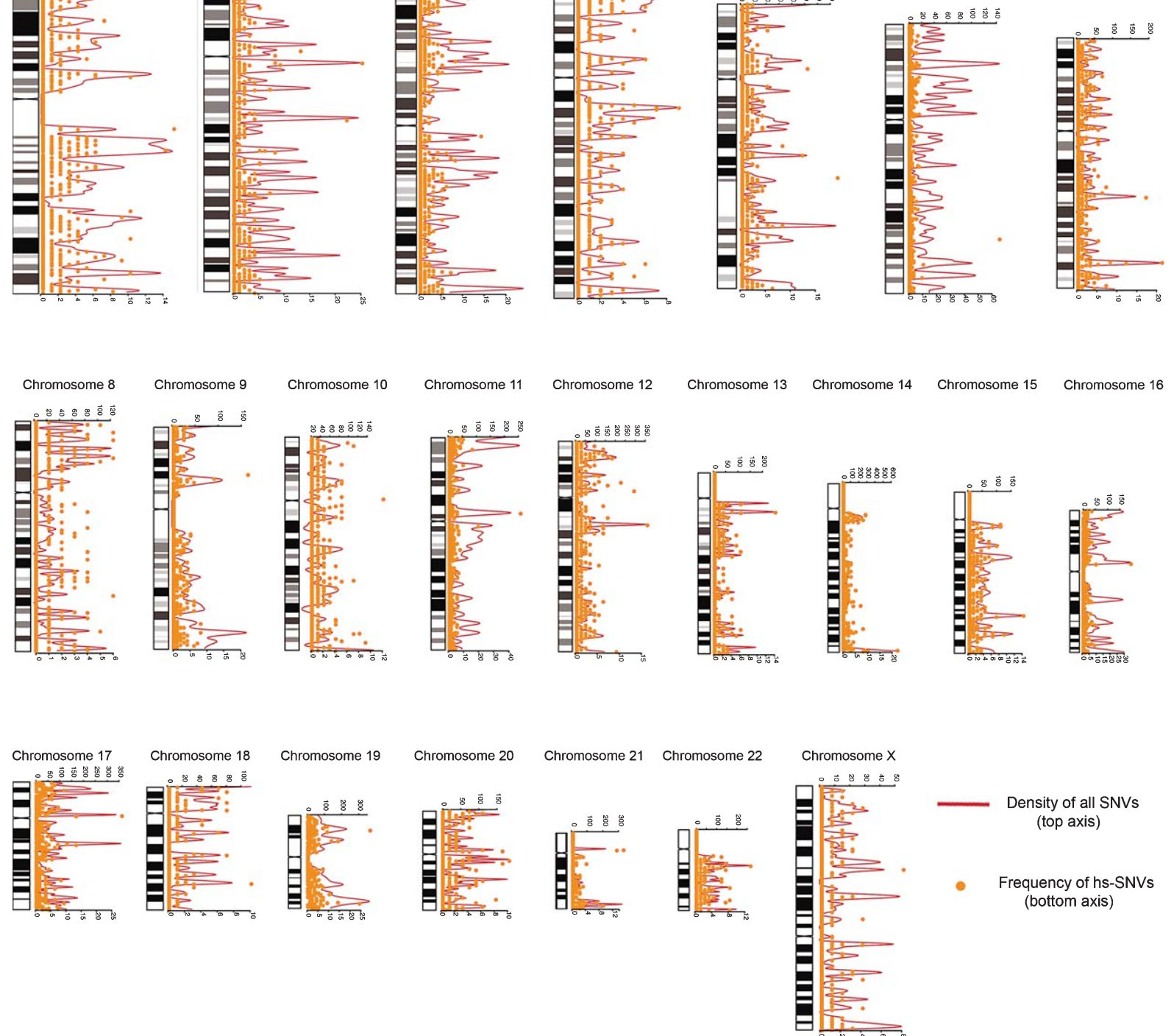
a

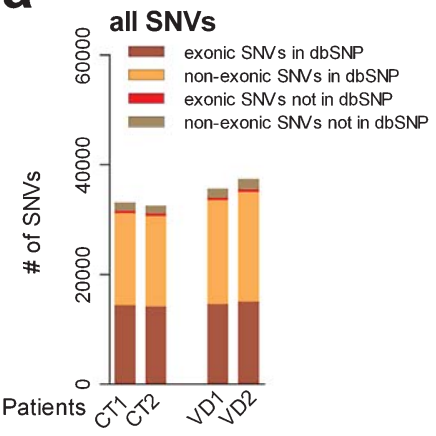

b

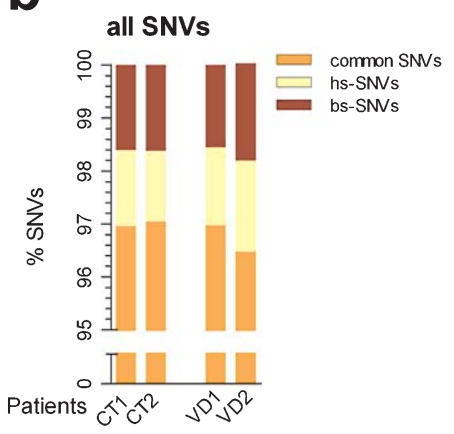

C

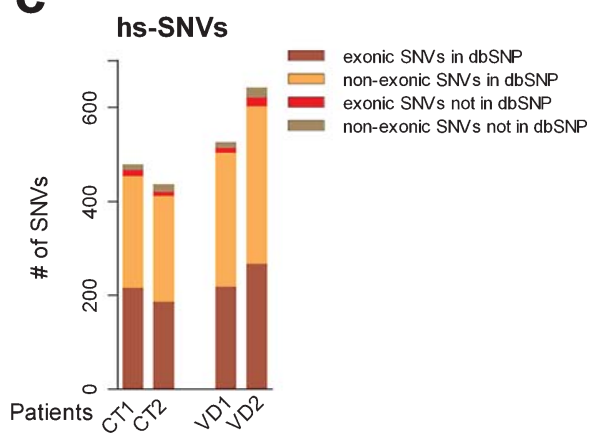

d

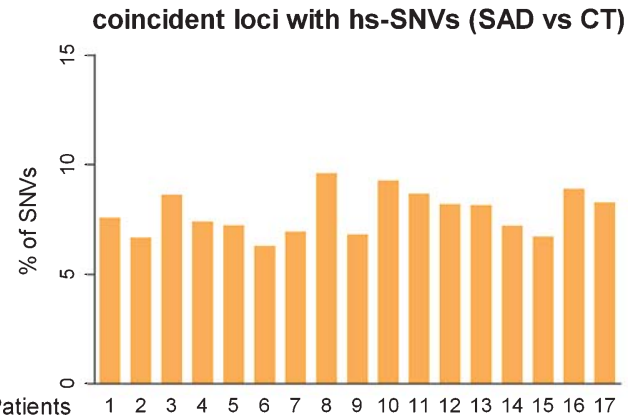

e f

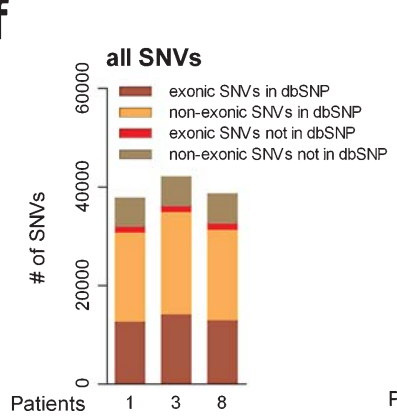

g

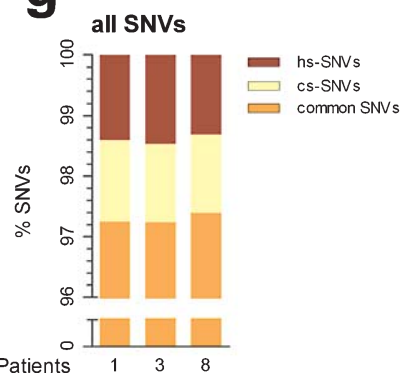

coincident loci with hs-SNVs (SAD vs VAD)

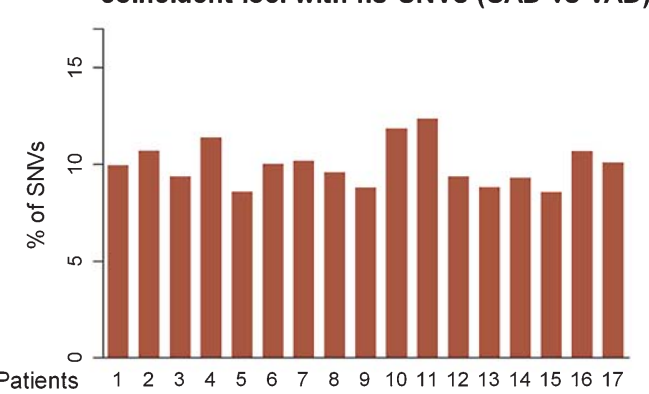

Fig. 4. Distribution and characteristics of hippocampus-specific (hs)-SNVs identified in control (CT) and vascular dementia (VaD) patients, and in the cerebella $(\mathrm{CB})$ of $3 \mathrm{SAD}$ patients. a) Distribution of SNVs/patient (CT and VaD), according to their annotation in dbSNP and their location in exonic and non-exonic regions. b) Percentage of blood-specific (bs), hs-, and common SNVs per sample. c) Number and classification of hs-SNVs/sample, according to their annotation in dbSNP and their location in exonic and non-exonic regions. d, e) Percentage of loci with hsSNVs in SAD samples which overlapped with hs-SNVs found in control and VaD brain samples. Overlap averaged $7.8 \%$ and $10 \%$, respectively. f) Distribution of SNVs found in the cerebella and blood of $3 \mathrm{SAD}$ patients, according to their annotation in dbSNP and their location in exonic and non-exonic regions. g) Percentage of blood-specific (bs), cerebellum-specific (cs), and common SNVs in three SAD patients. h) Number and classification of cs-SNVs/patient, according to their annotation in dbSNP and their location in exonic and non-exonic regions. i) Percentage of overlapping loci with brain-specific SNVs, in the cerebellum and hippocampus of three SAD patients. Note that most loci were specific either for the cerebellum or for the hippocampus.

in GWAS analyses with SAD and related dementias identified BIN1 (1 patient), ABCA7 (2 patients), and PICALM (1 patient) as genes bearing hs-SNVs (Supplementary Table 2). However, none of these hs-SNVs was coincident with the polymorphisms in the GWAS studies, although rs61748157 (BIN1) has been associ- ated with a recessive centronuclear myopathy [41]. Ten members of the ABC (ATP-binding cassette, ABCA) family, which transports lipids and cholesterol, bore hs-SNVs (Supplementary Tables 2 and 4).

We also screened for genes located in the chr21 critical region of Down syndrome which shares features 
with AD [42-44]. Up to 28 loci in the critical region exhibited hs-SNVs, with all 17 patients displaying at least one hs-SNVs (Supplementary Table 9). The most frequent loci were BAGE2 (8 patients), TPTE (6 patients), MX2 (6 patients), TIAM1 and EVA1C (5 patients) and HSF2BP (4 patients). BAGE2 and TPTE are included in the Robertsonian translocation region [42] and TPTE belongs to the PTEN phosphatase family related to multiple signaling cascades, including $\mathrm{p} 53 / \mathrm{p} 73$ [45, 46] and is associated with autism [47]. TIAM1 is a Rho guanine nucleotide exchange factor linked to TrkB signaling and dendritic spine physiology and plasticity, which is activated by $\mathrm{A} \beta[48,49]$. Finally, TTC3 (2 patients) encodes an E3 ligase that facilitates degradation of phosphorylated AKT [50], and NCAM2 (1 patient) has been implicated in prion disease, Down syndrome, SAD, and psychiatric disease susceptibility [51-55].

Other common loci exhibiting hs-SNVs and related to $\mathrm{A} \beta$ and SAD pathogenesis include CSMD1 (7 patients), LRP2 (Megalin), RYR2, PRUNE2, and SVIL (all of them in 6 patients), RYR1, LRP1B, ANKS1B, C3, and PION (all of them in 5 patients), and KALRN, NOS2, DCHS2 (4 patients) (Table 1 and Supplementary Table 4). PION (or GSAP) is a $\gamma$-secretase activating protein which increases $A \beta$ production $[56$, 57] and ANKS1B (or AIDA-1) binds the AID fragment of $\mathrm{A} \beta \mathrm{PP}$ and modulates $\mathrm{A} \beta \mathrm{PP} / \mathrm{A} \beta$ processing [58]. CHRNA7 ( $\alpha 7$ subunit of neuronal nicotinic actetylcholine receptor) regulates $\gamma$-secretase and reduces A $\beta P P$ processing, and is genetically associated with SAD and myoclonic epilepsy [59-61].

In addition, many recurrent loci bearing hs-SNVs have been implicated in neurodegeneration and in the pathogenesis of neurological and psychiatric diseases (Tables 1 and 2). For instance, the most recurrent loci (SYNE1) is a component of the nuclear lamina A complex that is mutated in neural diseases including cerebellar ataxia with spinal motorneuron disease [62, 63], autism [64], and Emery-Dreifuss muscular dystrophy $[65,66]$.

\section{Functions of hippocampus-specific loci bearing SNVs in $S A D$}

Our screening highlights genes involved in essential neuronal and biological functions (Tables 1 and 4 and Supplementary Table 4). Thus, in addition to genes linked to ion channel activity, neurotransmission, and synaptic-linked proteins (e.g., GRM7, PTK2B, RYR2, SYNE1, and TPTE), hs-SNV-containing loci regulate endoplasmic reticulum (ER)-to-Golgi trafficking and protein secretion, endocytosis and axonal/dendritic transport (e.g., DNAH3, 8, 11, and 14, PDE4DIP, SVIL, and several DOCK members), DNA-RNA metabolism/DNA damage response and genomic instability (e.g., PRIM2, HEATR1, MKI67, and CNOT), extracellular matrix/adhesion (FRAS1, COL27A1, DST, TNS1, and DCHS2) or muscular function (MYH13, NEB, DYSF, and OBSCN).

Further, hs-SNVs were identified in loci linked to functions which have been documented as risk factors for SAD: cardiac and vascular function, hypertension and blood circulation (e.g., CYP4F2, AKAP9, CASQ2, and BAZ2B), and cholesterol/lipid metabolism, and obesity/diabetes (e.g., MGAM, LRP2, FAT1, and LPA) (Table 4).

\section{Recurrent hippocampus-specific SNVs in SAD}

Many loci displayed several hs-SNVs (more than 2) in the same patient: for instance $7 \mathrm{hs}-\mathrm{SNV}$ s in the KIR3DL1 (patient 7), 6 hs-SNVs in the MAP2K3 gene (patients 5 and 12) and 6 hs-SNVs in the PTPN14 (patient 5) (Supplementary Table 4). In addition, several loci displayed recurrent hs-SNVs in the same positions (Table 3), suggesting that recurrent hs-SNVs target certain genes preferentially.

A search for recurrent mutations in SAD samples revealed that $19 \mathrm{hs}-\mathrm{SNV}$ positions were common to 3 patients (Fig. 5a, b, e.g., TMEM67, SGIP1, NLN, KNCTC1, PTPN1) and 517 additional hs-SNVs were shared by 2 SAD patients (Supplementary Table 8). Some of these repetitive hs-SNVs were in the most frequent SAD loci, including SYNE1, MAP2K3, OBSCN, PDE4DIP, and PTPN14.

We next analyzed the overlap between these recurrent SAD hs-SNVs and control samples (Supplementary Tables 2, 6, and 8). From the 19 most recurrent hs-SNVs in SAD (common to 3 patients; Fig. 5b and Supplementary Table 8), none were present in the hippocampus of control and $\mathrm{VaD}$ brains or in the three cerebellar samples (Fig. 5c; Supplementary Table 8). Such differential frequency of recurrent hs-SNVs, in SAD versus control tissue, also held true for the hs-SNVs found in 2 samples (Fig. 5c and Supplementary Table 8; 516 recurrent positions in 2 AD samples). Overall, each SAD sample displayed $\sim 64$ recurrent hs-SNVs (1089 hs-SNVs/17 samples) which were underrepresented in control brains ( $\sim 3.75$ hs-SNVs per Control; 15 hs-SNVs/4 samples). These data suggest that there is little overlap between recurrent hs-SNVs in SAD and control samples. 


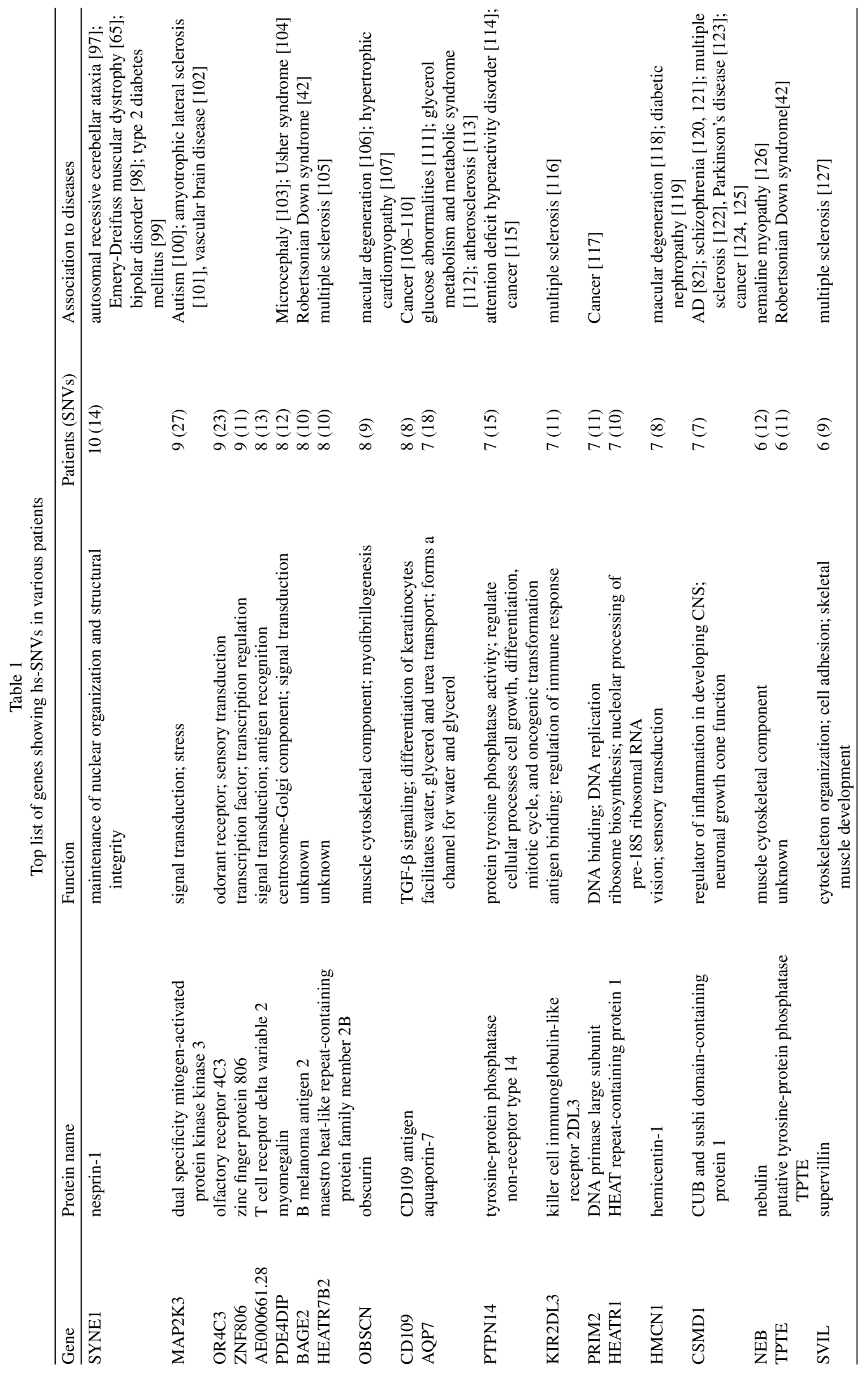




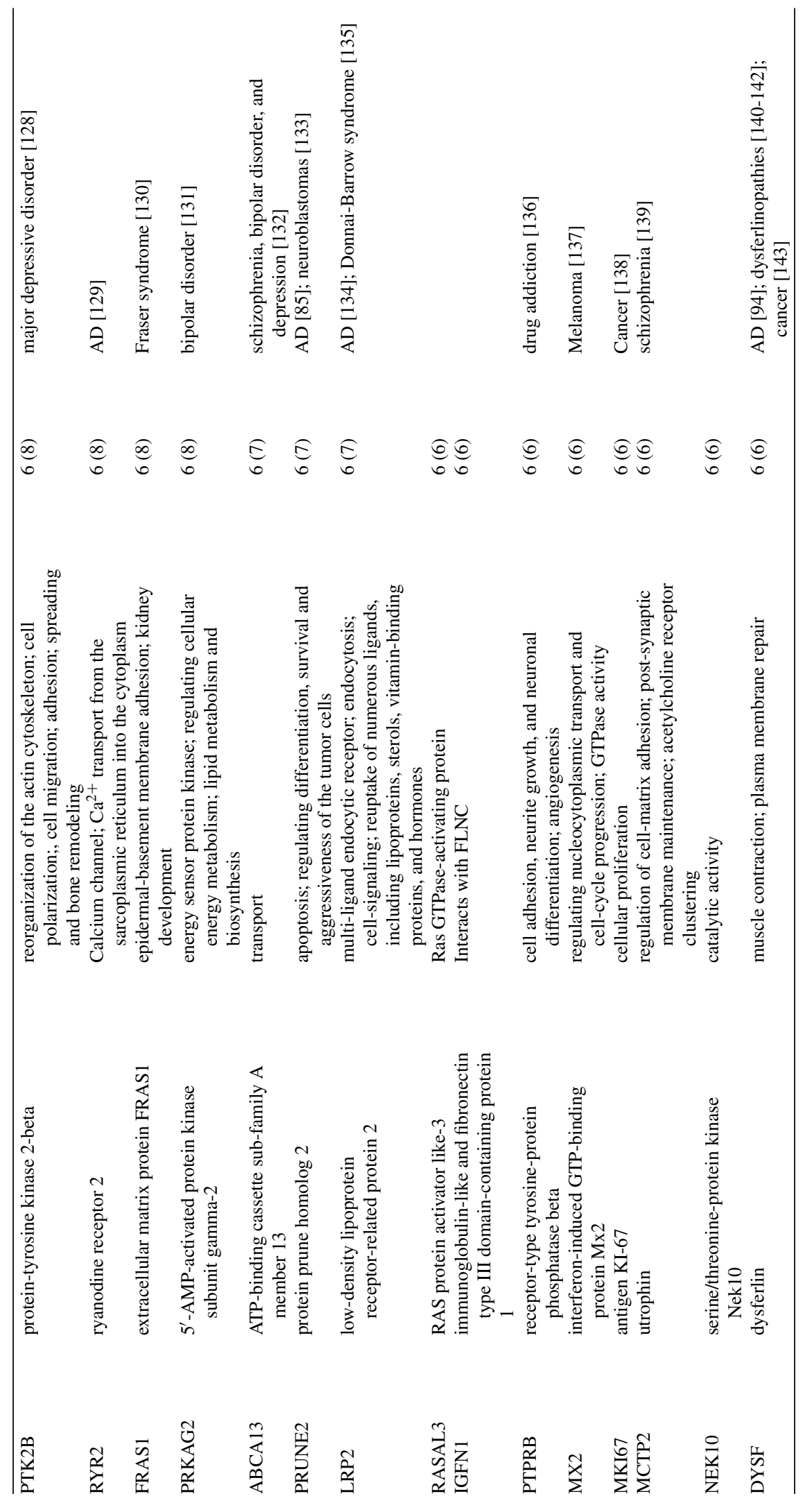




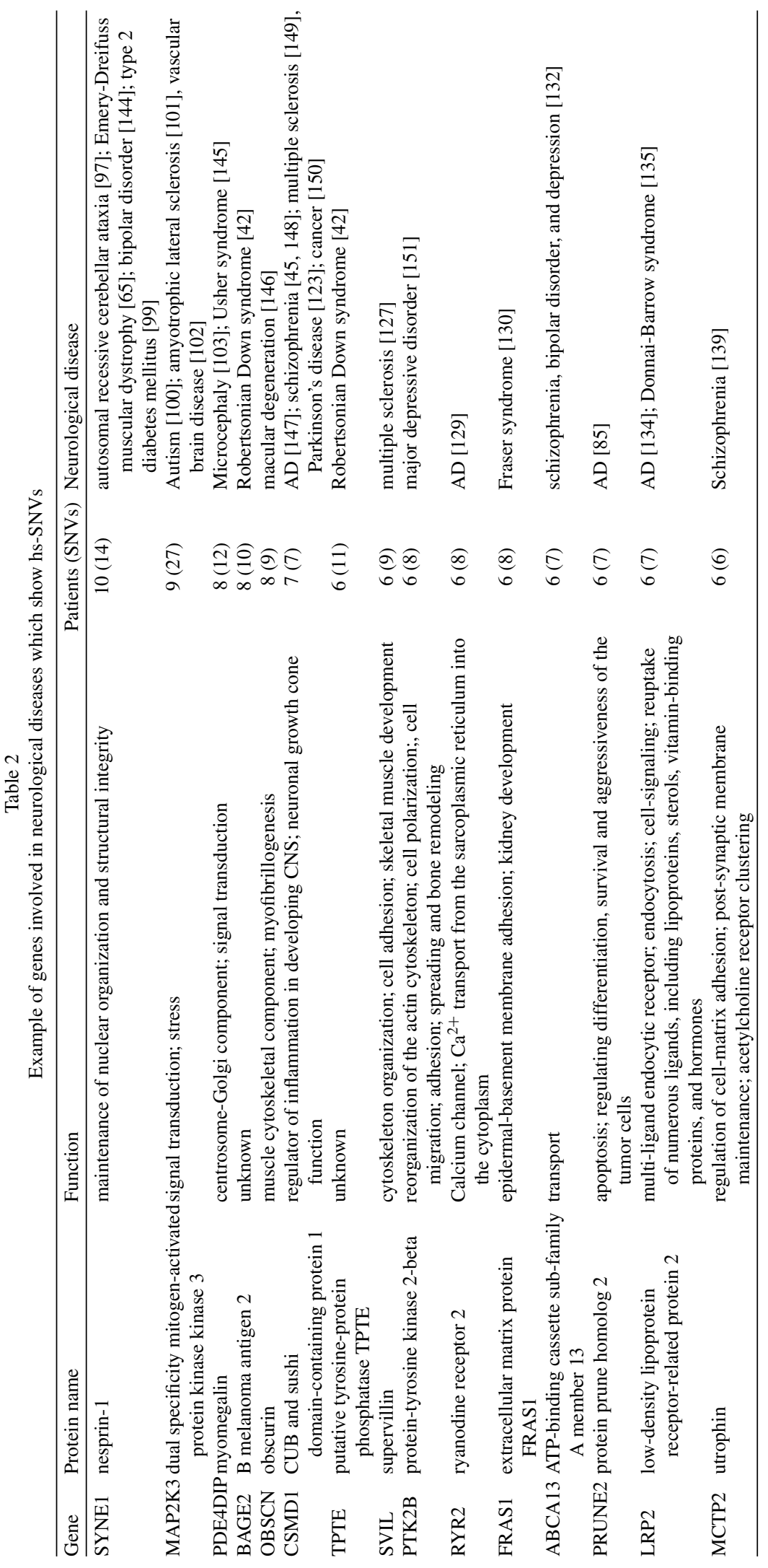




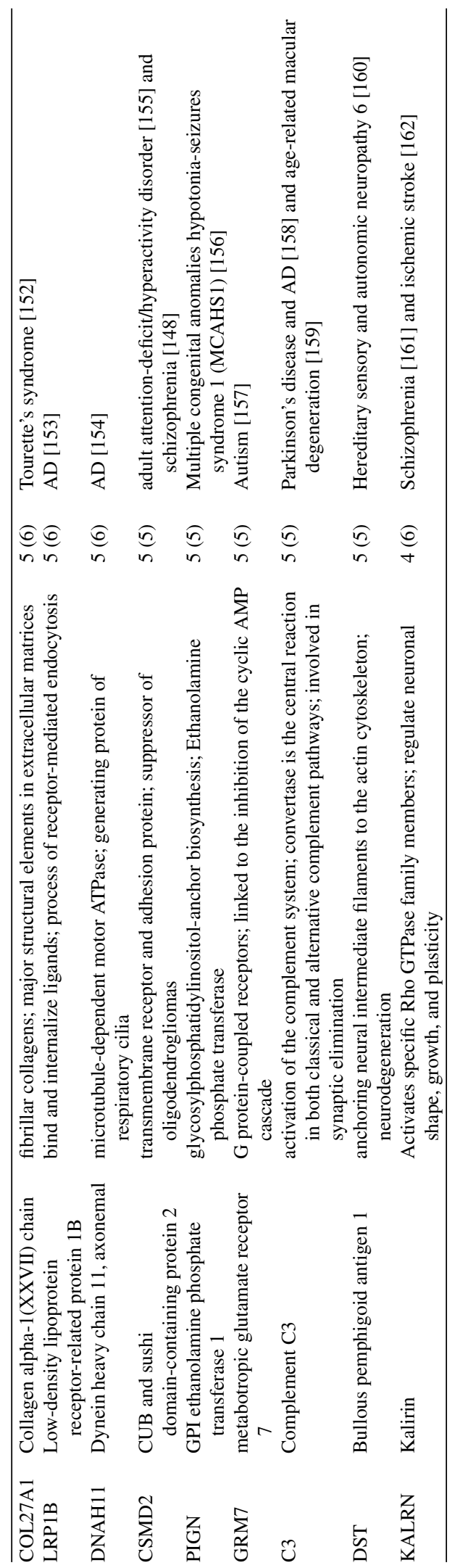




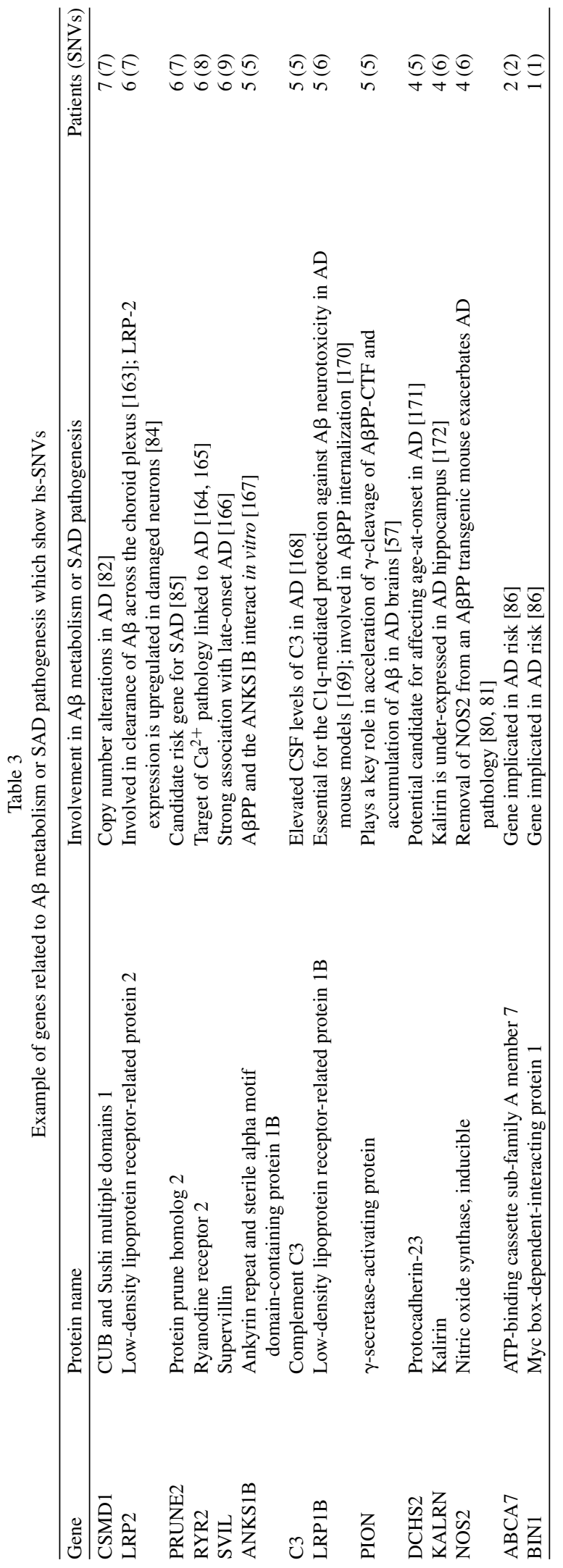


Table 4

Examples of genetic loci involved in essential neuronal and biological functions and molecular pathways

\begin{tabular}{|c|c|c|c|c|c|}
\hline $\begin{array}{l}\text { Neurotransmission; } \\
\text { ion channel } \\
\text { activity }\end{array}$ & $\begin{array}{l}\text { Extracellular } \\
\text { matrix } \\
\text { components; } \\
\text { adhesion }\end{array}$ & $\begin{array}{l}\text { DNA and } \\
\text { RNA } \\
\text { metabolism }\end{array}$ & $\begin{array}{l}\text { Protein trafficking and } \\
\text { secretion; axonal and } \\
\text { dendritic transport }\end{array}$ & $\begin{array}{l}\text { Muscle } \\
\text { function }\end{array}$ & Risk factors for SAD \\
\hline GRM7 & COL19A1 & CNOT1 & CEP104 & DYSF & Cardiac and vascular function \\
\hline PKD1L2 & COL27A1 & DDX11 & DNAH11 & MYH13 & RYR2 \\
\hline PTK2B & DCHS2 & DNMT1 & DNAH14 & NEB & CYP4F2 \\
\hline RYR2 & DDX60L & HEATR1 & DNAH3 & OBSCN & AKAP9 \\
\hline SYNE1 & DOCK4 & MKI67 & DNAH8 & SYNE1 & CASQ2 \\
\hline \multirow[t]{7}{*}{ TPTE } & DST & MLL3 & DOCK4 & & BAZ2B \\
\hline & FRAS1 & MOV10L1 & DST & & Lipid metabolism; diabetes \\
\hline & HMCN1 & PRIM2 & MYO5B & & LRP2 \\
\hline & LAMA4 & ZNF285 & NBEA & & PRKAG2 \\
\hline & PPFIBP2 & ZNF806 & PDE4DIP & & MGAM \\
\hline & PRR4 & & SVIL & & FAT1 \\
\hline & TNS1 & & & & LPA \\
\hline
\end{tabular}

\section{DISCUSSION}

The present whole-exome sequencing analyses show that the hippocampus of SAD patients displays a substantial, and constant ( 575), number of loci with SNVs which were not found in blood DNA from the same donors. Importantly, some of the genes bearing hs-SNVs were common in a large proportion of patients (e.g., 5 genes in 9 or more patients out of 17; see details in Supplementary Table 4) and 19 loci with important functions exhibited recurrent hsSNVs in 3 patients (e.g., TMEM67, SGIP1, NLN; Table 3). Finally, in addition to the large number of hs-SNVs with high functional impact, including nonsynonymous exonic variations and other events (e.g., start lost, stop gain, stop lost), hs-SNVs in intronic events may act as cis-regulatory elements and regulate transcriptional levels [67-69]. Taken together, our data suggest that a specific signature of hs-SNVs and wiring of the neuronal genome might contribute to the pathogenesis of SAD.

Recent studies using retrotransposon capture report the presence of somatic insertions of L1, Alu, and SVA retrotransposons in the human brain $(\sim 7,300$ for each whole genome sequence) suggesting somatic genome mosaicism [24, 25], with a large number of these insertions being intergenic and intronic, and some being predicted to lead to coding mutations. In the present study, we found an average of $\sim 575 \mathrm{hs}-\mathrm{SNV}$ s/sample after deep sequencing of the exome which covered about $\sim 1.2 \%$ of the human genome. Extrapolation of these data to the whole genome would suggest high genomic variability between blood and brain DNAs. Indeed, the number of hs-SNVs may be higher, given the large number of SNVs with low percentages of reads with the alternative allele, which may represent somatic mosaicism at the single neuronal level [25]. Thus, the present study, together with the deep retrotransposon insertional screenings [24] and the epigenetic regulation of the brain [70], suggests unexpected and complex wiring of the brain genome, in comparison to the human reference genome [27] and to the blood DNA from the same individuals.

As the number of hs-SNVs/patient exceeds the number of retrotransposon insertions [24], our data suggest that several genetic and molecular mechanisms may converge to the generation of somatic mosaicism. Somatic variations and mutations could arise from different DNA replication/repair and genetic mechanisms that take place during development or in adulthood $[25,71]$. The appearance of somatic mutations at very early developmental stages (either in blood or neural precursor cells) is likely to affect most of the cellular progeny. In fact, some hs-SNVs are de novo variations non-annotated in dbSNP. In addition, loss of heterozygosity occurs early in development [72]. Finally, some of the hs-SNVs displayed low, though highly significant, percentages of reads with a given allele, suggesting either somatic mutations at late stages of development in subsets of neuroglial progenitors [25] or genomic instability events taking place in the adult or as a consequence of the disease itself. Interestingly, recent studies have shown that $A \beta$ induces DNA double-strand breaks [73] and that control human neurons bear somatic CNVs in a mosaic-like manner [26]. Nevertheless, the exact mechanisms generating the reported brain variations remain to be determined.

The distribution of hs-SNVs along the human genome is uneven, targeting discrete genomic regions 
a
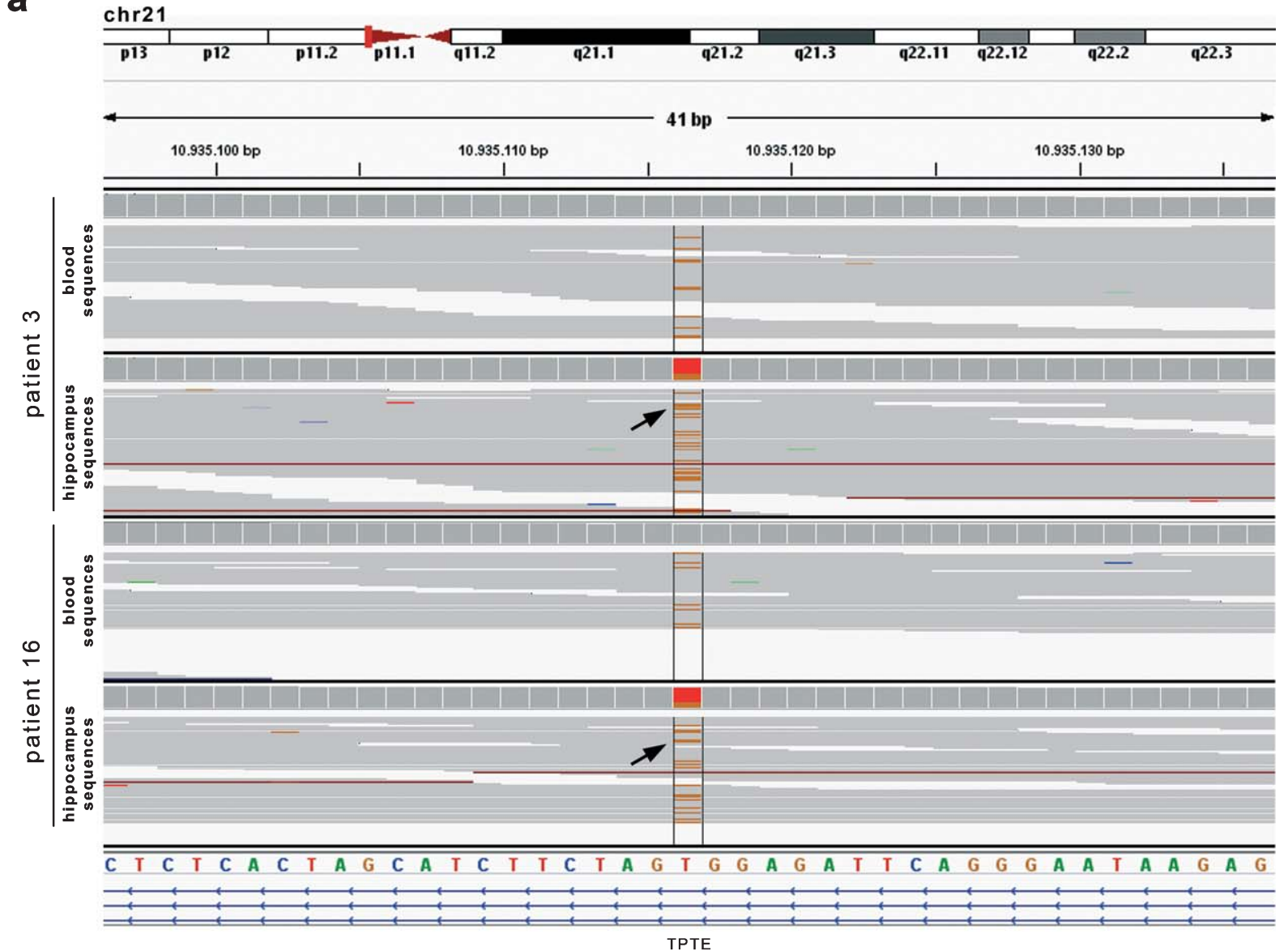

b

C

\begin{tabular}{|c|c|c|c|}
\hline \multicolumn{4}{|c|}{ Recurrent hs-SNYs in 3 SAD samples } \\
\hline $\begin{array}{l}\text { Chromosomal } \\
\text { position }\end{array}$ & Gene & Protein name & $\begin{array}{c}\text { Number of } \\
\text { samples }\end{array}$ \\
\hline chr1.67145322 & SGIP1 & SH3-containing GRB2-like protein 3-interacting protein 1 & 3 \\
\hline chr5.61697859 & DIMTIL & probable dimethyladenosine transferase & 3 \\
\hline chr5.65108215 & NLN & neurolysin $-l_{n}$ & 3 \\
\hline chr5.7695845 & $\mathrm{ADCY} 2$ & adenylabe cyclase type 2 & 3 \\
\hline chr8.87666251 & AC013751.1 & miRNA & 3 \\
\hline chr8.94808165 & TMEMG7 & Meckelin & 3 \\
\hline chr9.111735141 & CTNNALI & alpha-catulin & 3 \\
\hline chr9.130897759 & NA & - & 3 \\
\hline chr11.58140876 & $\mathrm{NA}$ & - & 3 \\
\hline chr11.67742518 & NA & - & 3 \\
\hline chr12.123105143 & KNTC1 & kinetochore-associabed protein 1 & 3 \\
\hline chr12.68435316 & GS1-410F4.3 & pseudogene & 3 \\
\hline chr13.19649804 & $\mathrm{NA}$ & - & 3 \\
\hline chr13.37580139 & EXOSC8 & exosome complex component RRP43 & 3 \\
\hline chr13.49761787 & FNDC3A & fibronectin type-III domain-containing protein $3 \mathrm{AA}$ & 3 \\
\hline chr13.75813554 & CTAGE11P & pseudogene & 3 \\
\hline chr16.58576490 & CNOT1 & CCR4-NOT transcription complex subunit 1 & 3 \\
\hline chr20.49191228 & PTPN1 & tyrosine-protein phosphatase non-receptor type 1 & 3 \\
\hline
\end{tabular}

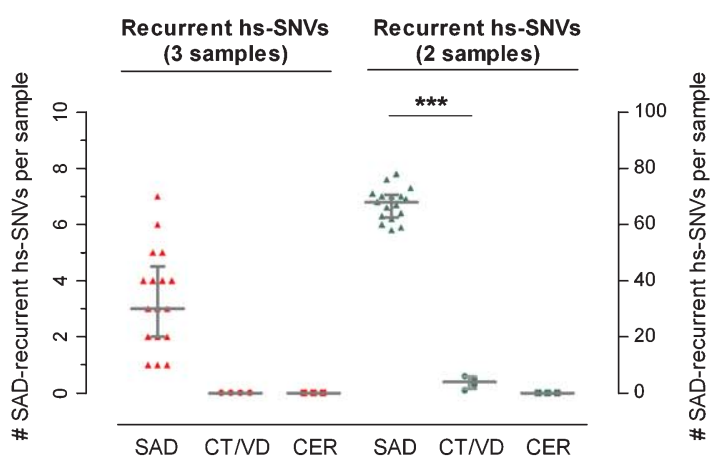

Fig. 5. a) IGV view showing detail of aligned reads to human genome demonstrating that two patients share $1 \mathrm{hs}$-SNVs (arrows) in the TPTE gene in chromosome 21. b) List of genes and chromosomal positions displaying recurrent hs-SNVs in 3 patients, out of 17. c) Average of recurrent hs-SNVs/patient in SAD and control hippocampi, and in the cerebellum of SAD patients. The averages are shown halved for the top recurrent hs-SNVs present in 3 or 2 patients (Mann-Witney $\mathrm{W}$ test; $* * * p \leq 0.001$ ). 
and even particular loci (Supplementary Table 4), which is consistent with L1 mutational insertion analysis [24], in which brain-specific retrotransposon insertions may correlate with transcriptionally active genes [24]. It has been proposed that somatic mutations are more likely to affect transcriptionally active open chromatin [74] and that DNA bases are oxidized (and modified) preferentially during transcription, with oxidized bases being removed by the Base-Excision Repair enzyme complex, thereby resulting in the appearance of somatic mutations $[75,76]$. On the other hand, factors related to aging and SAD progression, including tau and SIRT-1 proteins, increase oxidative stress and decrease DNA repair capacity, and they have all been implicated in neuronal DNA damage and repair [77-79]. Interestingly, some recurrent loci with hs-SNVs found in the present study target genes that play a role in DNA metabolism, instability and repair (e.g., PRIM2, DNMT1, HEATR1, MKI67, and PDE4DIP).

We did not detect pathogenic hs-SNVs in the A $\beta P P$, PSEN1, or PSEN2, the loci responsible for FAD. Large-scale GWAS analyses also failed to detect association of these genes with SAD [13], suggesting that mutations in these genes other than those reported in FAD may be rare or lethal. Some of the top genes bearing hs-SNVs, however, have been associated with $\mathrm{A} \beta \mathrm{PP}$ metabolism or $\mathrm{AD}$ genetics and pathogenesis. These include PION, LRP2, PRUNE2, CSMD1, BIN1, and NOS2 [57, 80-86] (Table 3). The data also highlight the possible involvement of novel loci and molecular pathways in SAD, the most enriched of which are neurotransmission and synaptic function, neurodegeneration and neural diseases, ERGolgi protein trafficking and transport, extracellular matrix/adhesion, DNA/RNA metabolism, repair and genomic instability (Table 4). Moreover, several of the identified loci encode for proteins with important functions in muscular physiology which are responsible for inherited neuromuscular disorders and dystrophies (e.g., DYSF, MYH13, NEB, OBSCN, and SYNE1) [87-93]. Some of these muscular proteins are highly expressed in brain, including amyloid deposits [94], and their mutations cause severe synaptic and neurological deficits $[91,95,96]$. A very recent GWAS meta-analysis reports several novel risk loci, among them PTK2B, INPP5D, and SORL1 [19]. Interestingly, our results show that these 3 loci bear hs-SNVs in 6 (PTK2B), 2 (INPP5D), and 1 (SORL1) patients (Table 2 and Supplementary Table 2) suggesting convergence of inherited and somatic genetic events on particular loci.
Lastly, we identified recurrent hs-SNVs in the hippocampus of SAD patients which were not present either in control hippocampi, or in the cerebellum of SAD patients (Fig. 5). Although further large scale genomic screening and functional studies are needed to confirm direct links between hs-SNVs and SAD pathogenesis and diagnosis, our results suggest novel chromosomal positions, loci and molecular pathways, targeted by hs-SNVs and relevant to neural function, that may participate in the pathogenesis of SAD.

In conclusion, our results suggest an unexpected number of somatic SNVs in the hippocampus of SAD and control patients which were not present in genomic blood DNA, suggesting that somatic brain wiring may be a natural consequence of aging. However, SAD samples display a specific somatic signature that might be important for the understanding of SAD pathogenesis and suggest the convergence of distinct genetic mechanisms and risk factors, from different origins (germline and somatic mosaicism), in the generation of both the common and differential traits of SAD phenotypes. Interestingly, it has recently been shown that amyloid leads to double-strand DNA breaks [73]. Globally, our data also indicate that hitherto unsuspected wiring and reshaping of the human brain genome may contribute to both human cognitive diversity and the pathogenesis of neurological diseases, opening up avenues for therapeutic interventions.

\section{ACKNOWLEDGMENTS}

This study was supported by grants from BBVA Foundation and MICINN-MINECO. We also like to thank the support of the Reina Sofia Foundation, the CIEN Foundation, CIBERNED (ISCIII), and grants BFU2008-3980 (ES) and SAF2006-02424 (JA) from MICINNN-MINECO. DR held a fellowship from MICINN-MINECO.

We thank Carlos López-Otín (University of Oviedo, Spain), Miguel Medina (CIBERNED, Madrid) and Margarita Salas (CBM, Madrid, Spain) for helpful comments and discussion.

Authors' disclosures available online (http://www. j-alz.com/disclosures/view.php?id=2336).

\section{SUPPLEMENTARY MATERIAL}

The supplementary material is available in the electronic version of this article: http://dx.doi.org/10.3233/ JAD-140891. 


\section{REFERENCES}

[1] Bertram L, Lill CM, Tanzi RE (2010) The genetics of Alzheimer disease: Back to the future. Neuron 68, 270-281.

[2] Selkoe DJ (2011) Alzheimer's disease. Cold Spring Harb Perspect Biol 3, pii: a004457.

[3] Ballard C, Gauthier S, Corbett A, Brayne C, Aarsland D, Jones E (2011) Alzheimer's disease. Lancet 377, 1019-1031.

[4] Rovelet-Lecrux A, Hannequin D, Raux G, Le Meur N, Laquerriere A, Vital A, Dumanchin C, Feuillette S, Brice A, Vercelletto M, Dubas F, Frebourg T, Campion D (2006) APP locus duplication causes autosomal dominant earlyonset Alzheimer disease with cerebral amyloid angiopathy. Nat Genet 38, 24-26.

[5] Barnes DE, Yaffe K (2011) The projected effect of risk factor reduction on Alzheimer's disease prevalence. Lancet Neurol 10, 819-828.

[6] Reitz C, Brayne C, Mayeux R (2011) Epidemiology of Alzheimer disease. Nat Rev Neurol 7, 137-152.

[7] Querfurth HW, LaFerla FM (2010) Alzheimer's disease. $N$ Engl J Med 362, 329-344.

[8] Strittmatter WJ, Saunders AM, Schmechel D, PericakVance M, Enghild J, Salvesen GS, Roses AD (1993) Apolipoprotein E: High-avidity binding to beta-amyloid and increased frequency of type 4 allele in late-onset familial Alzheimer disease. Proc Natl Acad Sci U S A 90, 1977-1981.

[9] Grupe A, Abraham R, Li Y, Rowland C, Hollingworth P, Morgan A, Jehu L, Segurado R, Stone D, Schadt E, Karnoub M, Nowotny P, Tacey K, Catanese J, Sninsky J, Brayne C, Rubinsztein D, Gill M, Lawlor B, Lovestone S, Holmans P, O'Donovan M, Morris JC, Thal L, Goate A, Owen MJ, Williams J (2007) Evidence for novel susceptibility genes for late-onset Alzheimer's disease from a genomewide association study of putative functional variants. Hum Mol Genet 16, 865-873.

[10] Jonsson T, Stefansson H, Steinberg S, Jonsdottir I, Jonsson PV, Snaedal J, Bjornsson S, Huttenlocher J, Levey AI, Lah JJ, Rujescu D, Hampel H, Giegling I, Andreassen OA, Engedal K, Ulstein I, Djurovic S, Ibrahim-Verbaas C, Hofman A, Ikram MA, van Duijn CM, Thorsteinsdottir U, Kong A, Stefansson K (2013) Variant of TREM2 associated with the risk of Alzheimer's disease. N Engl J Med 368, 107-116.

[11] Guerreiro R, Wojtas A, Bras J, Carrasquillo M, Rogaeva E, Majounie E, Cruchaga C, Sassi C, Kauwe JS, Younkin S, Hazrati L, Collinge J, Pocock J, Lashley T, Williams J, Lambert JC, Amouyel P, Goate A, Rademakers R, Morgan K, Powell J, St George-Hyslop P, Singleton A, Hardy J (2013) TREM2 variants in Alzheimer's disease. N Engl J Med 368, 117-127.

[12] Naj AC, Jun G, Beecham GW, Wang LS, Vardarajan BN, Buros J, Gallins PJ, Buxbaum JD, Jarvik GP, Crane PK, Larson EB, Bird TD, Boeve BF, Graff-Radford NR, De Jager PL, Evans D, Schneider JA, Carrasquillo MM, ErtekinTaner N, Younkin SG, Cruchaga C, Kauwe JS, Nowotny P, Kramer P, Hardy J, Huentelman MJ, Myers AJ, Barmada MM, Demirci FY, Baldwin CT, Green RC, Rogaeva E, St George-Hyslop P, Arnold SE, Barber R, Beach T, Bigio EH, Bowen JD, Boxer A, Burke JR, Cairns NJ, Carlson CS, Carney RM, Carroll SL, Chui HC, Clark DG, Corneveaux J, Cotman CW, Cummings JL, DeCarli C, DeKosky ST, DiazArrastia R, Dick M, Dickson DW, Ellis WG, Faber KM, Fallon KB, Farlow MR, Ferris S, Frosch MP, Galasko DR, Ganguli M, Gearing M, Geschwind DH, Ghetti B, Gilbert JR, Gilman S, Giordani B, Glass JD, Growdon JH, Hamilton RL, Harrell LE, Head E, Honig LS, Hulette CM, Hyman
BT, Jicha GA, Jin LW, Johnson N, Karlawish J, Karydas A, Kaye JA, Kim R, Koo EH, Kowall NW, Lah JJ, Levey AI, Lieberman AP, Lopez OL, Mack WJ, Marson DC, Martiniuk F, Mash DC, Masliah E, McCormick WC, McCurry SM, McDavid AN, McKee AC, Mesulam M, Miller BL, Miller CA, Miller JW, Parisi JE, Perl DP, Peskind E, Petersen RC, Poon WW, Quinn JF, Rajbhandary RA, Raskind M, Reisberg B, Ringman JM, Roberson ED, Rosenberg RN, Sano M, Schneider LS, Seeley W, Shelanski ML, Slifer MA, Smith CD, Sonnen JA, Spina S, Stern RA, Tanzi RE, Trojanowski JQ, Troncoso JC, Van Deerlin VM, Vinters HV, Vonsattel JP, Weintraub S, Welsh-Bohmer KA, Williamson J, Woltjer RL, Cantwell LB, Dombroski BA, Beekly D, Lunetta KL, Martin ER, Kamboh MI, Saykin AJ, Reiman EM, Bennett DA, Morris JC, Montine TJ, Goate AM, Blacker D, Tsuang DW, Hakonarson H, Kukull WA, Foroud TM, Haines JL, Mayeux R, Pericak-Vance MA, Farrer LA, Schellenberg GD (2011) Common variants at MS4A4/MS4A6E, CD2AP, CD33 and EPHA1 are associated with late-onset Alzheimer's disease. Nat Genet 43, 436-441.

[13] Tanzi RE (2012) The genetics of Alzheimer disease. Cold Spring Harb Perspect Med 2, pii: a006296.

[14] Lambert JC, Heath S, Even G, Campion D, Sleegers K Hiltunen M, Combarros O, Zelenika D, Bullido MJ, Tavernier B, Letenneur L, Bettens K, Berr C, Pasquier F, Fievet N, Barberger-Gateau P, Engelborghs S, De Deyn P, Mateo I, Franck A, Helisalmi S, Porcellini E, Hanon O, de Pancorbo MM, Lendon C, Dufouil C, Jaillard C, Leveillard T, Alvarez V, Bosco P, Mancuso M, Panza F, Nacmias B, Bossu P, Piccardi P, Annoni G, Seripa D, Galimberti D, Hannequin D, Licastro F, Soininen H, Ritchie K, Blanche H, Dartigues JF, Tzourio C, Gut I, Van Broeckhoven C, Alperovitch A, Lathrop M, Amouyel P (2009) Genome-wide association study identifies variants at CLU and CR1 associated with Alzheimer's disease. Nat Genet 41, 1094-1099.

[15] Hollingworth P, Harold D, Sims R, Gerrish A, Lambert JC, Carrasquillo MM, Abraham R, Hamshere ML, Pahwa JS, Moskvina V, Dowzell K, Jones N, Stretton A, Thomas C, Richards A, Ivanov D, Widdowson C, Chapman J, Lovestone S, Powell J, Proitsi P, Lupton MK, Brayne C, Rubinsztein DC, Gill M, Lawlor B, Lynch A, Brown KS, Passmore PA, Craig D, McGuinness B, Todd S, Holmes C, Mann D, Smith AD, Beaumont H, Warden D, Wilcock G, Love S, Kehoe PG, Hooper NM, Vardy ER, Hardy J, Mead S, Fox NC, Rossor M, Collinge J, Maier W, Jessen F, Ruther E, Schurmann B, Heun R, Kolsch H, van den Bussche H, Heuser I, Kornhuber J, Wiltfang J, Dichgans M, Frolich L, Hampel H, Gallacher J, Hull M, Rujescu D, Giegling I, Goate AM, Kauwe JS, Cruchaga C, Nowotny P, Morris JC, Mayo K, Sleegers K, Bettens K, Engelborghs S, De Deyn PP, Van Broeckhoven C, Livingston G, Bass NJ, Gurling H, McQuillin A, Gwilliam R, Deloukas P, AlChalabi A, Shaw CE, Tsolaki M, Singleton AB, Guerreiro R, Muhleisen TW, Nothen MM, Moebus S, Jockel KH, Klopp N, Wichmann HE, Pankratz VS, Sando SB, Aasly JO, Barcikowska M, Wszolek ZK, Dickson DW, GraffRadford NR, Petersen RC, van Duijn CM, Breteler MM, Ikram MA, DeStefano AL, Fitzpatrick AL, Lopez O, Launer LJ, Seshadri S, Berr C, Campion D, Epelbaum J, Dartigues JF, Tzourio C, Alperovitch A, Lathrop M, Feulner TM, Friedrich P, Riehle C, Krawczak M, Schreiber S, Mayhaus M, Nicolhaus S, Wagenpfeil S, Steinberg S, Stefansson H, Stefansson K, Snaedal J, Bjornsson S, Jonsson PV, Chouraki V, Genier-Boley B, Hiltunen M, Soininen H, Combarros O, Zelenika D, Delepine M, Bullido MJ, Pasquier F, Mateo I, 
Frank-Garcia A, Porcellini E, Hanon O, Coto E, Alvarez V, Bosco P, Siciliano G, Mancuso M, Panza F, Solfrizzi V, Nacmias B, Sorbi S, Bossu P, Piccardi P, Arosio B, Annoni G, Seripa D, Pilotto A, Scarpini E, Galimberti D, Brice A, Hannequin D, Licastro F, Jones L, Holmans PA, Jonsson T, Riemenschneider M, Morgan K, Younkin SG, Owen MJ, O'Donovan M, Amouyel P, Williams J (2011) Common variants at ABCA7, MS4A6A/MS4A4E, EPHA1, CD33 and CD2AP are associated with Alzheimer's disease. Nat Genet 43, 429-435.

[16] Harold D, Abraham R, Hollingworth P, Sims R, Gerrish A, Hamshere ML, Pahwa JS, Moskvina V, Dowzell K, Williams A, Jones N, Thomas C, Stretton A, Morgan AR, Lovestone S, Powell J, Proitsi P, Lupton MK, Brayne C, Rubinsztein DC, Gill M, Lawlor B, Lynch A, Morgan K, Brown KS, Passmore PA, Craig D, McGuinness B, Todd S, Holmes C, Mann D, Smith AD, Love S, Kehoe PG, Hardy J, Mead S, Fox N, Rossor M, Collinge J, Maier W, Jessen F, Schurmann B, van den Bussche H, Heuser I, Kornhuber J, Wiltfang J, Dichgans M, Frolich L, Hampel H, Hull M, Rujescu D, Goate AM, Kauwe JS, Cruchaga C, Nowotny P, Morris JC, Mayo K, Sleegers K, Bettens K, Engelborghs S, De Deyn PP, Van Broeckhoven C, Livingston G, Bass NJ, Gurling H, McQuillin A, Gwilliam R, Deloukas P, Al-Chalabi A, Shaw CE, Tsolaki M, Singleton AB, Guerreiro R, Muhleisen TW, Nothen MM, Moebus S, Jockel KH, Klopp N, Wichmann HE, Carrasquillo MM, Pankratz VS, Younkin SG, Holmans PA, O'Donovan M, Owen MJ, Williams J (2009) Genome-wide association study identifies variants at CLU and PICALM associated with Alzheimer's disease. Nat Genet 41, 1088-1093.

[17] Bradshaw EM, Chibnik LB, Keenan BT, Ottoboni L, Raj T, Tang A, Rosenkrantz LL, Imboywa S, Lee M, Von Korff A, Morris MC, Evans DA, Johnson K, Sperling RA, Schneider JA, Bennett DA, De Jager PL (2013) CD33 Alzheimer's disease locus: Altered monocyte function and amyloid biology. Nat Neurosci 16, 848-850.

[18] Griciuc A, Serrano-Pozo A, Parrado AR, Lesinski AN, Asselin CN, Mullin K, Hooli B, Choi SH, Hyman BT, Tanzi RE (2013) Alzheimer's disease risk gene CD33 inhibits microglial uptake of amyloid beta. Neuron 78, 631-643.

[19] Lambert JC, Ibrahim-Verbaas CA, Harold D, Naj AC, Sims R, Bellenguez C, Jun G, Destefano AL, Bis JC, Beecham GW, Grenier-Boley B, Russo G, Thornton-Wells TA, Jones N, Smith AV, Chouraki V, Thomas C, Ikram MA, Zelenika D, Vardarajan BN, Kamatani Y, Lin CF, Gerrish A, Schmidt H, Kunkle B, Dunstan ML, Ruiz A, Bihoreau MT, Choi SH, Reitz C, Pasquier F, Hollingworth P, Ramirez A, Hanon O, Fitzpatrick AL, Buxbaum JD, Campion D, Crane PK, Baldwin C, Becker T, Gudnason V, Cruchaga C, Craig D, Amin N, Berr C, Lopez OL, De Jager PL, Deramecourt V, Johnston JA, Evans D, Lovestone S, Letenneur L, Moron FJ, Rubinsztein DC, Eiriksdottir G, Sleegers K, Goate AM, Fievet N, Huentelman MJ, Gill M, Brown K, Kamboh MI, Keller L, Barberger-Gateau P, McGuinness B, Larson EB, Green R, Myers AJ, Dufouil C, Todd S, Wallon D, Love S, Rogaeva E, Gallacher J, St George-Hyslop P, Clarimon J, Lleo A, Bayer A, Tsuang DW, Yu L, Tsolaki M, Bossu P, Spalletta G, Proitsi P, Collinge J, Sorbi S, Sanchez-Garcia F, Fox NC, Hardy J, Naranjo MC, Bosco P, Clarke R, Brayne C, Galimberti D, Mancuso M, Matthews F, Moebus S, Mecocci P, Del Zompo M, Maier W, Hampel H, Pilotto A, Bullido M, Panza F, Caffarra P, Nacmias B, Gilbert JR, Mayhaus M, Lannfelt L, Hakonarson H, Pichler S, Carrasquillo MM, Ingelsson M, Beekly D, Alvarez V, Zou F, Valladares O,
Younkin SG, Coto E, Hamilton-Nelson KL, Gu W, Razquin C, Pastor P, Mateo I, Owen MJ, Faber KM, Jonsson PV, Combarros O, O’Donovan MC, Cantwell LB, Soininen H, Blacker D, Mead S, Mosley TH, Jr., Bennett DA, Harris TB, Fratiglioni L, Holmes C, de Bruijn RF, Passmore P, Montine TJ, Bettens K, Rotter JI, Brice A, Morgan K, Foroud TM, Kukull WA, Hannequin D, Powell JF, Nalls MA, Ritchie K, Lunetta KL, Kauwe JS, Boerwinkle E, Riemenschneider M, Boada M, Hiltunen M, Martin ER, Schmidt R, Rujescu D, Wang LS, Dartigues JF, Mayeux R, Tzourio C, Hofman A, Nothen MM, Graff C, Psaty BM, Jones L, Haines JL, Holmans PA, Lathrop M, Pericak-Vance MA, Launer LJ, Farrer LA, van Duijn CM, Van Broeckhoven C, Moskvina V, Seshadri S, Williams J, Schellenberg GD, Amouyel P (2013) Meta-analysis of 74,046 individuals identifies 11 new susceptibility loci for Alzheimer's disease. Nat Genet 45, 1452-1458.

[20] Foulkes WD (2008) Inherited susceptibility to common cancers. N Engl J Med 359, 2143-2153.

[21] Peltomaki P (2012) Mutations and epimutations in the origin of cancer. Exp Cell Res 318, 299-310.

[22] Wheeler HE, Maitland ML, Dolan ME, Cox NJ, Ratain MJ (2013) Cancer pharmacogenomics: Strategies and challenges. Nat Rev Genet 14, 23-34.

[23] Puente XS, Pinyol M, Quesada V, Conde L, Ordonez GR, Villamor N, Escaramis G, Jares P, Bea S, Gonzalez-Diaz M, Bassaganyas L, Baumann T, Juan M, Lopez-Guerra M, Colomer D, Tubio JM, Lopez C, Navarro A, Tornador C, Aymerich M, Rozman M, Hernandez JM, Puente DA, Freije JM, Velasco G, Gutierrez-Fernandez A, Costa D, Carrio A, Guijarro S, Enjuanes A, Hernandez L, Yague J, Nicolas P, Romeo-Casabona CM, Himmelbauer H, Castillo E, Dohm JC, de Sanjose S, Piris MA, de Alava E, San Miguel J, Royo R, Gelpi JL, Torrents D, Orozco M, Pisano DG, Valencia A, Guigo R, Bayes M, Heath S, Gut M, Klatt P, Marshall J, Raine K, Stebbings LA, Futreal PA, Stratton MR, Campbell PJ, Gut I, Lopez-Guillermo A, Estivill X, Montserrat E, Lopez-Otin C, Campo E (2011) Whole-genome sequencing identifies recurrent mutations in chronic lymphocytic leukaemia. Nature 475, 101-105.

[24] Baillie JK, Barnett MW, Upton KR, Gerhardt DJ, Richmond TA, De Sapio F, Brennan PM, Rizzu P, Smith S, Fell M, Talbot RT, Gustincich S, Freeman TC, Mattick JS, Hume DA, Heutink P, Carninci P, Jeddeloh JA, Faulkner GJ (2011) Somatic retrotransposition alters the genetic landscape of the human brain. Nature 479, 534-537.

[25] Evrony Gilad D, Cai X, Lee E, Hills LB, Elhosary PC, Lehmann Hillel S, Parker JJ, Atabay Kutay D, Gilmore Edward C, Poduri A, Park Peter J, Walsh Christopher A (2012) Single-neuron sequencing analysis of L1 retrotransposition and somatic mutation in the human brain. Cell 151, 483-496.

[26] McConnell MJ, Lindberg MR, Brennand KJ, Piper JC, Voet T, Cowing-Zitron C, Shumilina S, Lasken RS, Vermeesch JR, Hall IM, Gage FH (2013) Mosaic copy number variation in human neurons. Science 342, 632-637.

[27] Lander ES, Linton LM, Birren B, Nusbaum C, Zody MC, Baldwin J, Devon K, Dewar K, Doyle M, FitzHugh W, Funke R, Gage D, Harris K, Heaford A, Howland J, Kann L, Lehoczky J, LeVine R, McEwan P, McKernan K, Meldrim J, Mesirov JP, Miranda C, Morris W, Naylor J, Raymond C, Rosetti M, Santos R, Sheridan A, Sougnez C, StangeThomann N, Stojanovic N, Subramanian A, Wyman D, Rogers J, Sulston J, Ainscough R, Beck S, Bentley D, Burton J, Clee C, Carter N, Coulson A, Deadman R, Deloukas 
P, Dunham A, Dunham I, Durbin R, French L, Grafham D, Gregory S, Hubbard T, Humphray S, Hunt A, Jones M, Lloyd C, McMurray A, Matthews L, Mercer S, Milne S, Mullikin JC, Mungall A, Plumb R, Ross M, Shownkeen R, Sims S, Waterston RH, Wilson RK, Hillier LW, McPherson JD, Marra MA, Mardis ER, Fulton LA, Chinwalla AT, Pepin KH, Gish WR, Chissoe SL, Wendl MC, Delehaunty KD, Miner TL, Delehaunty A, Kramer JB, Cook LL, Fulton RS, Johnson DL, Minx PJ, Clifton SW, Hawkins T, Branscomb E, Predki P, Richardson P, Wenning S, Slezak T, Doggett N, Cheng JF, Olsen A, Lucas S, Elkin C, Uberbacher E, Frazier M, Gibbs RA, Muzny DM, Scherer SE, Bouck JB, Sodergren EJ, Worley KC, Rives CM, Gorrell JH, Metzker ML, Naylor SL, Kucherlapati RS, Nelson DL, Weinstock GM, Sakaki Y, Fujiyama A, Hattori M, Yada T, Toyoda A, Itoh T, Kawagoe C, Watanabe H, Totoki Y, Taylor T, Weissenbach J, Heilig R, Saurin W, Artiguenave F, Brottier P, Bruls T, Pelletier E, Robert C, Wincker P, Smith DR, Doucette-Stamm L, Rubenfield M, Weinstock K, Lee HM, Dubois J, Rosenthal A, Platzer M, Nyakatura G, Taudien S, Rump A, Yang H, Yu J, Wang J, Huang G, Gu J, Hood L, Rowen L, Madan A, Qin S, Davis RW, Federspiel NA, Abola AP, Proctor MJ, Myers RM, Schmutz J, Dickson M, Grimwood J, Cox DR, Olson MV, Kaul R, Raymond C, Shimizu N, Kawasaki K, Minoshima S, Evans GA, Athanasiou M, Schultz R, Roe BA, Chen F, Pan H, Ramser J, Lehrach H, Reinhardt R, McCombie WR, de la Bastide M, Dedhia N, Blocker H, Hornischer K, Nordsiek G, Agarwala R, Aravind L, Bailey JA, Bateman A, Batzoglou S, Birney E, Bork P, Brown DG, Burge CB, Cerutti L, Chen HC, Church D, Clamp M, Copley RR, Doerks T, Eddy SR, Eichler EE, Furey TS, Galagan J, Gilbert JG, Harmon C, Hayashizaki Y, Haussler D, Hermjakob H, Hokamp K, Jang W, Johnson LS, Jones TA, Kasif S, Kaspryzk A, Kennedy S, Kent WJ, Kitts P, Koonin EV, Korf I, Kulp D, Lancet D, Lowe TM, McLysaght A, Mikkelsen T, Moran JV, Mulder N, Pollara VJ, Ponting CP, Schuler G, Schultz J, Slater G, Smit AF, Stupka E, Szustakowski J, Thierry-Mieg D, Thierry-Mieg J, Wagner L, Wallis J, Wheeler R, Williams A, Wolf YI, Wolfe KH, Yang SP, Yeh RF, Collins F, Guyer MS, Peterson J, Felsenfeld A, Wetterstrand KA, Patrinos A, Morgan MJ, de Jong P, Catanese JJ, Osoegawa K, Shizuya H, Choi S, Chen YJ (2001) Initial sequencing and analysis of the human genome. Nature $\mathbf{4 0 9}$, 860-921.

[28] Li H, Durbin R (2009) Fast and accurate long-read alignment with Burrows-Wheeler transform. Bioinformatics 26, 589595.

[29] Nunomura A, Chiba S, Kosaka K, Takeda A, Castellani RJ, Smith MA, Perry G (2002) Neuronal RNA oxidation is a prominent feature of dementia with Lewy bodies. Neuroreport 13, 2035-2039.

[30] McKenna A, Hanna M, Banks E, Sivachenko A, Cibulskis K, Kernytsky A, Garimella K, Altshuler D, Gabriel S, Daly M, DePristo MA (2010) The Genome Analysis Toolkit: A MapReduce framework for analyzing next-generation DNA sequencing data. Genome Res 20, 1297-1303.

[31] Barnett DW, Garrison EK, Quinlan AR, Strömberg MP, Marth GT (2011) BamTools: A C++API and toolkit for analyzing and managing BAM files. Bioinformatics 27, 1691-1692.

[32] DePristo MA, Banks E, Poplin R, Garimella KV, Maguire JR, Hartl C, Philippakis AA, del Angel G, Rivas MA, Hanna M, McKenna A, Fennell TJ, Kernytsky AM, Sivachenko AY, Cibulskis K, Gabriel SB, Altshuler D, Daly MJ (2011) A framework for variation discovery and genotyping using next-generation DNA sequencing data. Nat Genet $\mathbf{4 3}$, 491498.

[33] Drew KL, Toien O, Rivera PM, Smith MA, Perry G, Rice ME (2002) Role of the antioxidant ascorbate in hibernation and warming from hibernation. Comp Biochem Physiol C Toxicol Pharmacol 133, 483-492.

[34] Sherry ST, Ward MH, Kholodov M, Baker J, Phan L, Smigielski EM, Sirotkin K (2001) dbSNP: The NCBI database of genetic variation. Nucleic Acids Res 29, 308311.

[35] Fujita PA, Rhead B, Zweig AS, Hinrichs AS, Karolchik D, Cline MS, Goldman M, Barber GP, Clawson H, Coelho A, Diekhans M, Dreszer TR, Giardine BM, Harte RA, HillmanJackson J, Hsu F, Kirkup V, Kuhn RM, Learned K, Li CH, Meyer LR, Pohl A, Raney BJ, Rosenbloom KR, Smith KE, Haussler D, Kent WJ (2010) The UCSC Genome Browser database: Update 2011. Nucleic Acids Res 39, D876D882.

[36] Cingolani P (2012) snpEff: Variant effect prediction, http://snpeff.sourceforge.net.

[37] De Baets G, Van Durme J, Reumers J, Maurer-Stroh S, Vanhee P, Dopazo J, Schymkowitz J, Rousseau F (2012) SNPeffect 4.0: On-line prediction of molecular and structural effects of protein-coding variants. Nucleic Acids Res 40, D935-D939.

[38] Meyer LR, Zweig AS, Hinrichs AS, Karolchik D, Kuhn RM, Wong M, Sloan CA, Rosenbloom KR, Roe G, Rhead B, Raney BJ, Pohl A, Malladi VS, Li CH, Lee BT, Learned K, Kirkup V, Hsu F, Heitner S, Harte RA, Haeussler M, Guruvadoo L, Goldman M, Giardine BM, Fujita PA, Dreszer TR, Diekhans M, Cline MS, Clawson H, Barber GP, Haussler D, Kent WJ (2013) The UCSC Genome Browser database: Extensions and updates 2013. Nucleic Acids Res 41(Database issue), D64-D69.

[39] Cingolani P, Platts A, Wang le L, Coon M, Nguyen T, Wang L, Land SJ, Lu X, Ruden DM (2012) A program for annotating and predicting the effects of single nucleotide polymorphisms, SnpEff: SNPs in the genome of Drosophila melanogaster strain w1118; iso-2; iso-3. Fly (Austin) 6, 8092.

[40] Dursun E, Gezen-Ak D, Eker E, Ertan T, Engin F, Hanagasi H, Gurvit H, Emre M, Yilmazer S (2008) Presenilin-1 gene intronic polymorphism and late-onset Alzheimer's disease. $J$ Geriatr Psychiatry Neurol 21, 268-273.

[41] Nicot A-S, Toussaint A, Tosch V, Kretz C, WallgrenPettersson C, Iwarsson E, Kingston H, Garnier J-M, Biancalana V, Oldfors A, Mandel J-L, Laporte J (2007) Mutations in amphiphysin 2 (BIN1) disrupt interaction with dynamin 2 and cause autosomal recessive centronuclear myopathy. Nat Genet 39, 1134-1139.

[42] Shaw SW, Chen CP, Cheng PJ, Wang TH, Hou JW, Lin CT, Chang SD, Hwa HL, Lin JL, Chao AS, Soong YK, Hsieh FJ (2008) Gene dosage change of TPTE and BAGE2 and breakpoint analysis in Robertsonian Down syndrome. J Hum Genet 53, 136-143.

[43] Mann DM, Esiri MM (1989) The pattern of acquisition of plaques and tangles in the brains of patients under 50 years of age with Down's syndrome. J Neurol Sci 89, 169-179.

[44] Prasher VP (1993) Presenile dementia associated with unbalanced Robertsonian translocation form of Down's syndrome. Lancet 342, 686-687.

[45] Tapparel C, Reymond A, Girardet C, Guillou L, Lyle R, Lamon C, Hutter P, Antonarakis SE (2003) The TPTE gene family: Cellular expression, subcellular localization and alternative splicing. Gene 323, 189-199. 
[46] Walker SM, Downes CP, Leslie NR (2001) TPIP: A novel phosphoinositide 3-phosphatase. Biochem J 360, 277283.

[47] Rodriguez-Escudero I, Oliver MD, Andres-Pons A, Molina M, Cid VJ, Pulido R (2011) A comprehensive functional analysis of PTEN mutations: Implications in tumor- and autism-related syndromes. Hum Mol Genet 20, 4132-4142.

[48] Miller MB, Yan Y, Eipper BA, Mains RE (2013) Neuronal Rho GEFs in synaptic physiology and behavior. Neuroscientist 19, 255-273.

[49] Mendoza-Naranjo A, Gonzalez-Billault C, Maccioni RB (2007) Abeta1-42 stimulates actin polymerization in hippocampal neurons through Rac1 and Cdc42 Rho GTPases. J Cell Sci 120, 279-288.

[50] Suizu F, Hiramuki Y, Okumura F, Matsuda M, Okumura AJ, Hirata N, Narita M, Kohno T, Yokota J, Bohgaki M, Obuse C, Hatakeyama S, Obata T, Noguchi M (2009) The E3 ligase TTC3 facilitates ubiquitination and degradation of phosphorylated Akt. Dev Cell 17, 800-810.

[51] Gratacos M, Costas J, de Cid R, Bayes M, Gonzalez JR, Baca-Garcia E, de Diego Y, Fernandez-Aranda F, Fernandez-Piqueras J, Guitart M, Martin-Santos R, Martorell L, Menchon JM, Roca M, Saiz-Ruiz J, Sanjuan J, Torrens M, Urretavizcaya M, Valero J, Vilella E, Estivill X, Carracedo A (2009) Identification of new putative susceptibility genes for several psychiatric disorders by association analysis of regulatory and non-synonymous SNPs of 306 genes involved in neurotransmission and neurodevelopment. Am J Med Genet B Neuropsychiatr Genet 150B, 808-816.

[52] Schmitt-Ulms G, Hansen K, Liu J, Cowdrey C, Yang J, DeArmond SJ, Cohen FE, Prusiner SB, Baldwin MA (2004) Time-controlled transcardiac perfusion cross-linking for the study of protein interactions in complex tissues. Nat Biotechnol 22, 724-731.

[53] Yashin AI, Wu D, Arbeev KG, Ukraintseva SV (2010) Joint influence of small-effect genetic variants on human longevity. Aging (Albany NY) 2, 612-620.

[54] Haldeman-Englert CR, Chapman KA, Kruger H, Geiger EA, McDonald-McGinn DM, Rappaport E, Zackai EH, Spinner NB, Shaikh TH (2010) A de novo 8.8-Mb deletion of 21q21.1-q21.3 in an autistic male with a complex rearrangement involving chromosomes 6, 10, and 21. Am JMed Genet A 152A 196-202.

[55] Han MR, Schellenberg GD, Wang LS (2011) Genome-wide association reveals genetic effects on human Abeta42 and tau protein levels in cerebrospinal fluids: A case control study. BMC Neurol 10, 90.

[56] He G, Luo W, Li P, Remmers C, Netzer WJ, Hendrick J, Bettayeb K, Flajolet M, Gorelick F, Wennogle LP, Greengard P (2010) Gamma-secretase activating protein is a therapeutic target for Alzheimer's disease. Nature 467, 95-98.

[57] Satoh J, Tabunoki H, Ishida T, Saito Y, Arima K (2012) Immunohistochemical characterization of gamma-secretase activating protein expression in Alzheimer's disease brains Neuropathol Appl Neurobiol 38, 132-141.

[58] Ghersi E, Noviello C, D’Adamio L (2004) Amyloidbeta protein precursor (AbetaPP) intracellular domainassociated protein-1 proteins bind to AbetaPP and modulate its processing in an isoform-specific manner. $\mathrm{J}$ Biol Chem 279, 49105-49112.

[59] Shinawi M, Schaaf CP, Bhatt SS, Xia Z, Patel A, Cheung SW, Lanpher B, Nagl S, Herding HS, Nevinny-Stickel C, Immken LL, Patel GS, German JR, Beaudet AL, Stankiewicz P (2009) A small recurrent deletion within
$15 q 13.3$ is associated with a range of neurodevelopmental phenotypes. Nat Genet 41, 1269-1271.

[60] Heinzen EL, Need AC, Hayden KM, Chiba-Falek O, Roses AD, Strittmatter WJ, Burke JR, Hulette CM, Welsh-Bohmer KA, Goldstein DB (2010) Genome-wide scan of copy number variation in late-onset Alzheimer's disease. J Alzheimers Dis 19, 69-77.

[61] Nie HZ, Shi S, Lukas RJ, Zhao WJ, Sun YN, Yin M (2010) Activation of alpha7 nicotinic receptor affects APP processing by regulating secretase activity in SH-EP1-alpha7 nAChR-hAPP695 cells. Brain Res 1356, 112-120.

[62] Izumi Y, Miyamoto R, Morino H, Yoshizawa A, Nishinaka K, Udaka F, Kameyama M, Maruyama H, Kawakami H (2013) Cerebellar ataxia with SYNE1 mutation accompanying motor neuron disease. Neurology 80, 600-601.

[63] Gros-Louis F, Dupre N, Dion P, Fox MA, Laurent S, Verreault S, Sanes JR, Bouchard J-P, Rouleau GA (2007) Mutations in SYNE1 lead to a newly discovered form of autosomal recessive cerebellar ataxia. Nat Genet 39, 80-85.

[64] Yu TW, Chahrour MH, Coulter ME, Jiralerspong S, Okamura-Ikeda K, Ataman B, Schmitz-Abe K, Harmin DA, Adli M, Malik AN, D’Gama AM, Lim ET, Sanders SJ, Mochida GH, Partlow JN, Sunu CM, Felie JM, Rodriguez J, Nasir RH, Ware J, Joseph RM, Hill RS, Kwan BY, AlSaffar M, Mukaddes NM, Hashmi A, Balkhy S, Gascon GG, Hisama FM, LeClair E, Poduri A, Oner O, Al-Saad S, AlAwadi SA, Bastaki L, Ben-Omran T, Teebi AS, Al-Gazali L, Eapen V, Stevens CR, Rappaport L, Gabriel SB, Markianos K, State MW, Greenberg ME, Taniguchi H, Braverman NE, Morrow EM, Walsh CA (2013) Using whole-exome sequencing to identify inherited causes of autism. Neuron 77, 259-273.

[65] Zhang Q, Bethmann C, Worth NF, Davies JD, Wasner C, Feuer A, Ragnauth CD, Yi Q, Mellad JA, Warren DT, Wheeler MA, Ellis JA, Skepper JN, Vorgerd M, SchlotterWeigel B, Weissberg PL, Roberts RG, Wehnert M, Shanahan CM (2007) Nesprin-1 and -2 are involved in the pathogenesis of Emery Dreifuss muscular dystrophy and are critical for nuclear envelope integrity. Hum Mol Genet 16, 2816-2833.

[66] Wheeler MA, Davies JD, Zhang Q, Emerson LJ, Hunt J, Shanahan CM, Ellis JA (2007) Distinct functional domains in nesprin-1alpha and nesprin-2beta bind directly to emerin and both interactions are disrupted in X-linked EmeryDreifuss muscular dystrophy. Exp Cell Res 313, 2845-2857.

[67] Feschotte C (2008) Transposable elements and the evolution of regulatory networks. Nat Rev Genet 9, 397-405.

[68] Maher B (2012) ENCODE: The human encyclopaedia. Nature 489, 46-48.

[69] Gerstein M (2012) Genomics: ENCODE leads the way on big data. Nature 489, 208.

[70] Xin Y, Chanrion B, O’Donnell AH, Milekic M, Costa R, Ge Y, Haghighi FG (2012) MethylomeDB: A database of DNA methylation profiles of the brain. Nucleic Acids Res 40, D1245-D1249.

[71] Poduri A, Evrony GD, Cai X, Elhosary PC, Beroukhim R, Lehtinen MK, Hills LB, Heinzen EL, Hill A, Hill RS, Barry BJ, Bourgeois BF, Riviello JJ, Barkovich AJ, Black PM, Ligon KL, Walsh CA (2012) Somatic activation of AKT3 causes hemispheric developmental brain malformations. Neuron 74, 41-48.

[72] Huijsmans CJ, Poodt J, Damen J, van der Linden JC, Savelkoul PH, Pruijt JF, Hilbink M, Hermans MH (2012) Single nucleotide polymorphism (SNP)-based loss of heterozygosity $(\mathrm{LOH})$ testing by real time PCR in patients suspect of myeloproliferative disease. PLoS One 7, e38362. 
[73] Suberbielle E, Sanchez PE, Kravitz AV, Wang X, Ho K, Eilertson K, Devidze N, Kreitzer AC, Mucke L (2013) Physiologic brain activity causes DNA double-strand breaks in neurons, with exacerbation by amyloid-beta. Nat Neurosci 16, 613-621.

[74] Cost GJ, Golding A, Schlissel MS, Boeke JD (2001) Target DNA chromatinization modulates nicking by L1 endonuclease. Nucleic Acids Res 29, 573-577.

[75] Weissman L, Jo DG, Sorensen MM, de Souza-Pinto NC, Markesbery WR, Mattson MP, Bohr VA (2007) Defective DNA base excision repair in brain from individuals with Alzheimer's disease and amnestic mild cognitive impairment. Nucleic Acids Res 35, 5545-5555.

[76] Marchesi VT (2011) Alzheimer's dementia begins as a disease of small blood vessels, damaged by oxidative-induced inflammation and dysregulated amyloid metabolism: Implications for early detection and therapy. FASEB $J$ 25, 5-13.

[77] Sultan A, Nesslany F, Violet M, Begard S, Loyens A, Talahari S, Mansuroglu Z, Marzin D, Sergeant N, Humez S, Colin M, Bonnefoy E, Buee L, Galas MC (2011) Nuclear tau, a key player in neuronal DNA protection. $J$ Biol Chem 286, 4566-4575.

[78] Lu T, Pan Y, Kao SY, Li C, Kohane I, Chan J, Yankner BA (2004) Gene regulation and DNA damage in the ageing human brain. Nature 429, 883-891.

[79] Fishel ML, Vasko MR, Kelley MR (2007) DNA repair in neurons: So if they don't divide what's to repair? Mutat Res 614, 24-36.

[80] Colton CA, Wilcock DM, Wink DA, Davis J, Van Nostrand WE, Vitek MP (2008) The effects of NOS2 gene deletion on mice expressing mutated human AbetaPP. J Alzheimers Dis 15, 571-587.

[81] Wilcock DM, Lewis MR, Van Nostrand WE, Davis J, Previti ML, Gharkholonarehe N, Vitek MP, Colton CA (2008) Progression of amyloid pathology to Alzheimer's disease pathology in an amyloid precursor protein transgenic mouse model by removal of nitric oxide synthase 2. J Neurosci $\mathbf{2 8}$, 1537-1545.

[82] Swaminathan S, Kim S, Shen L, Risacher SL, Foroud T, Pankratz N, Potkin SG, Huentelman MJ, Craig DW, Weiner MW, Saykin AJ, The Alzheimer's Disease Neuroimaging Initiative A (2011) Genomic copy number analysis in Alzheimer's disease and mild cognitive impairment: An ADNI study. Int J Alzheimers Dis 2011, 729478.

[83] Alvira-Botero X, Carro EM (2010) Clearance of amyloidbeta peptide across the choroid plexus in Alzheimer's disease. Curr Aging Sci 3, 219-229.

[84] LaFerla FM, Troncoso JC, Strickland DK, Kawas CH, Jay G (1997) Neuronal cell death in Alzheimer's disease correlates with apoE uptake and intracellular Abeta stabilization. J Clin Invest 100, 310-320.

[85] Potkin SG, Guffanti G, Lakatos A, Turner JA, Kruggel F, Fallon JH, Saykin AJ, Orro A, Lupoli S, Salvi E, Weiner M, Macciardi F (2009) Hippocampal atrophy as a quantitative trait in a genome-wide association study identifying novel susceptibility genes for Alzheimer's disease. PLoS One 4, e6501.

[86] Schellenberg GD, Montine TJ (2012) The genetics and neuropathology of Alzheimer's disease. Acta Neuropathol 124, 305-323.

[87] Paradas C, Llauger J, Diaz-Manera J, Rojas-Garcia R, De Luna N, Iturriaga C, Marquez C, Uson M, Hankiewicz K, Gallardo E, Illa I (2010) Redefining dysferlinopathy phenotypes based on clinical findings and muscle imaging studies. Neurology 75, 316-323.
[88] Ohlsson M, Hedberg C, Bradvik B, Lindberg C, Tajsharghi H, Danielsson O, Melberg A, Udd B, Martinsson T, Oldfors A (2012) Hereditary myopathy with early respiratory failure associated with a mutation in A-band titin. Brain 135, 16821694.

[89] Labeit S, Ottenheijm CA, Granzier H (2011) Nebulin, a major player in muscle health and disease. FASEB $J \mathbf{2 5}$, 822-829.

[90] Tajsharghi H, Oldfors A (2013) Myosinopathies: Pathology and mechanisms. Acta Neuropathol 125, 3-18.

[91] Perronnet C, Vaillend C (2010) Dystrophins, utrophins, and associated scaffolding complexes: Role in mammalian brain and implications for therapeutic strategies. J Biomed Biotechnol 2010, 849426.

[92] McElhinny AS, Kazmierski ST, Labeit S, Gregorio CC (2003) Nebulin: The nebulous, multifunctional giant of striated muscle. Trends Cardiovasc Med 13, 195-201.

[93] Carlsson L, Yu JG, Thornell LE (2008) New aspects of obscurin in human striated muscles. Histochem Cell Biol 130, 91-103.

[94] Galvin JE, Palamand D, Strider J, Milone M, Pestronk A (2006) The muscle protein dysferlin accumulates in the Alzheimer brain. Acta Neuropathol 112, 665-671.

[95] Charizanis K, Lee KY, Batra R, Goodwin M, Zhang C, Yuan Y, Shiue L, Cline M, Scotti MM, Xia G, Kumar A, Ashizawa T, Clark HB, Kimura T, Takahashi MP, Fujimura H, Jinnai K, Yoshikawa H, Gomes-Pereira M, Gourdon G, Sakai N, Nishino S, Foster TC, Ares M, Jr., Darnell RB, Swanson MS (2012) Muscleblind-like 2-mediated alternative splicing in the developing brain and dysregulation in myotonic dystrophy. Neuron 75, 437-450.

[96] Franc DT, Muetzel RL, Robinson PR, Rodriguez CP, Dalton JC, Naughton CE, Mueller BA, Wozniak JR, Lim KO, Day JW (2012) Cerebral and muscle MRI abnormalities in myotonic dystrophy. Neuromuscul Disord 22, 483-491.

[97] Dupre N, Gros-Louis F, Bouchard JP, Noreau A, Rouleau GA (1993) SYNE1-related autosomal recessive cerebellar ataxia. In GeneReviews ${ }^{\circledR}$ [Internet], Pagon RA, Adam MP, Ardinger HH, Bird TD, Dolan CR, Fong CT, Smith RJH, Stephens K, ed. University of Washington Seattle, 19932014.

[98] Smith EN, Koller DL, Panganiban C, Szelinger S, Zhang P, Badner JA, Barrett TB, Berrettini WH, Bloss CS, Byerley W, Coryell W, Edenberg HJ, Foroud T, Gershon ES, Greenwood TA, Guo Y, Hipolito M, Keating BJ, Lawson WB, Liu C, Mahon PB, McInnis MG, McMahon FJ, McKinney R, Murray SS, Nievergelt CM, Nurnberger JI Jr, Nwulia EA, Potash JB, Rice J, Schulze TG, Scheftner WA, Shilling PD, Zandi PP, Zollner S, Craig DW, Schork NJ, Kelsoe JR (2011) Genome-wide association of bipolar disorder suggests an enrichment of replicable associations in regions near genes. PLoS Genet 7, e1002134.

[99] Scott LJ, Mohlke KL, Bonnycastle LL, Willer CJ, Li Y, Duren WL, Erdos MR, Stringham HM, Chines PS, Jackson AU, Prokunina-Olsson L, Ding CJ, Swift AJ, Narisu N, Hu T, Pruim R, Xiao R, Li XY, Conneely KN, Riebow NL, Sprau AG, Tong M, White PP, Hetrick KN, Barnhart MW, Bark CW, Goldstein JL, Watkins L, Xiang F, Saramies J, Buchanan TA, Watanabe RM, Valle TT, Kinnunen L, Abecasis GR, Pugh EW, Doheny KF, Bergman RN, Tuomilehto J, Collins FS, Boehnke M (2007) A genome-wide association study of type 2 diabetes in Finns detects multiple susceptibility variants. Science 316, 1341-1345.

[100] Garbett K, Ebert PJ, Mitchell A, Lintas C, Manzi B, Mirnics K, Persico AM (2008) Immune transcriptome alterations in 
the temporal cortex of subjects with autism. Neurobiol Dis 30, 303-311.

[101] Holasek SS, Wengenack TM, Kandimalla KK, Montano C, Gregor DM, Curran GL, Poduslo JF (2005) Activation of the stress-activated MAP kinase, p38, but not JNK in cortical motor neurons during early presymptomatic stages of amyotrophic lateral sclerosis in transgenic mice. Brain Res 1045, 185-198.

[102] Zhu Y, Sun Y, Xie L, Jin K, Sheibani N, Greenberg DA (2003) Hypoxic induction of endoglin via mitogen-activated protein kinases in mouse brain microvascular endothelial cells. Stroke 34, 2483-2488.

[103] Bond J, Woods CG (2006) Cytoskeletal genes regulating brain size. Curr Opin Cell Biol 18, 95-101.

[104] Overlack N, Kilic D, Bauss K, Marker T, Kremer H, van Wijk E, Wolfrum U Direct interaction of the Usher syndrome $1 \mathrm{G}$ protein SANS and myomegalin in the retina. Biochim Biophys Acta 1813, 1883-1892.

[105] Kallio SP, Jakkula E, Purcell S, Suvela M, Koivisto K, Tienari PJ, Elovaara I, Pirttila T, Reunanen M, Bronnikov D, Viander M, Meri S, Hillert J, Lundmark F, Harbo HF, Lorentzen AR, De Jager PL, Daly MJ, Hafler DA, Palotie A, Peltonen L, Saarela J (2009) Use of a genetic isolate to identify rare disease variants: $\mathrm{C} 7$ on $5 \mathrm{p}$ associated with $\mathrm{MS}$. Hum Mol Genet 18, 1670-1683.

[106] Lynch SM, Frei B (1997) Physiological thiol compounds exert pro- and anti-oxidant effects, respectively, on iron- and copper-dependent oxidation of human low-density lipoprotein. Biochim Biophys Acta 1345, 215-221.

[107] Arimura T, Matsumoto Y, Okazaki O, Hayashi T, Takahashi M, Inagaki N, Hinohara K, Ashizawa N, Yano K, Kimura A (2007) Structural analysis of obscurin gene in hypertrophic cardiomyopathy. Biochem Biophys Res Commun 362, 281 287.

[108] Hasegawa M, Hagiwara S, Sato T, Jijiwa M, Murakumo Y, Maeda M, Moritani S, Ichihara S, Takahashi M (2007) CD109, a new marker for myoepithelial cells of mammary, salivary, and lacrimal glands and prostate basal cells. Pathol Int 57, 245-250.

[109] Ohshima Y, Yajima I, Kumasaka MY, Yanagishita T, Watanabe D, Takahashi M, Inoue Y, Ihn H, Matsumoto Y, Kato M (2010) CD109 expression levels in malignant melanoma. $J$ Dermatol Sci 57, 140-142.

[110] Hagikura M, Murakumo Y, Hasegawa M, Jijiwa M, Hagiwara S, Mii S, Hagikura S, Matsukawa Y, Yoshino Y, Hattori R, Wakai K, Nakamura S, Gotoh M, Takahashi M (2010) Correlation of pathological grade and tumor stage of urothelial carcinomas with CD109 expression. Pathol Int 60, 735-743.

[111] Miranda M, Ceperuelo-Mallafre V, Lecube A, Hernandez C, Chacon MR, Fort JM, Gallart L, Baena-Fustegueras JA, Simo R, Vendrell J (2009) Gene expression of paired abdominal adipose AQP7 and liver AQP9 in patients with morbid obesity: Relationship with glucose abnormalities. Metabolism 58, 1762-1768.

[112] Maeda N Implications of aquaglyceroporins 7 and 9 in glycerol metabolism and metabolic syndrome. Mol Aspects Med 33, 665-675.

[113] He ZQ, Liang C, Wang H, Wu ZG (2008) Dysfunction of AQP7 in the periadventitial fat: A novel trigger of atherosclerosis. Med Hypotheses 70, 92-95.

[114] Neale BM, Lasky-Su J, Anney R, Franke B, Zhou K, Maller JB, Vasquez AA, Asherson P, Chen W, Banaschewski T, Buitelaar J, Ebstein R, Gill M, Miranda A, Oades RD, Roeyers H, Rothenberger A, Sergeant J, Steinhausen HC,
Sonuga-Barke E, Mulas F, Taylor E, Laird N, Lange C, Daly M, Faraone SV (2008) Genome-wide association scan of attention deficit hyperactivity disorder. Am J Med Genet $B$ Neuropsychiatr Genet 147B, 1337-1344.

[115] Wyatt L, Khew-Goodall Y (2008) PTP-Pez: A novel regulator of TGFbeta signaling. Cell Cycle 7, 2290-2295.

[116] Jelcic I, Hsu KC, Kakalacheva K, Breiden P, Dupont B, Uhrberg M, Martin R, Munz C, Lunemann JD Killer immunoglobulin-like receptor locus polymorphisms in multiple sclerosis. Mult Scler 18, 951-958.

[117] Yatsula B, Galvao C, McCrann M, Perkins AS (2006) Assessment of F-MuLV-induced tumorigenesis reveals new candidate tumor genes including Pecam1, St7, and Prim2. Leukemia 20, 162-165.

[118] Thompson CL, Klein BE, Klein R, Xu Z, Capriotti J, Joshi T, Leontiev D, Lee KE, Elston RC, Iyengar SK (2007) Complement factor $\mathrm{H}$ and hemicentin-1 in age-related macular degeneration and renal phenotypes. Hum Mol Genet 16, 2135-2148.

[119] Kim S, Abboud HE, Pahl MV, Tayek J, Snyder S, Tamkin J, Alcorn H Jr, Ipp E, Nast CC, Elston RC, Iyengar SK, Adler SG. Examination of association with candidate genes for diabetic nephropathy in a Mexican American population. Clin J Am Soc Nephrol 5, 1072-1078.

[120] Schizophrenia-Psychiatric-GWAS-Consortium (2011) Genome-wide association study identifies five new schizophrenia loci. Nat Genet 43, 969-976.

[121] Havik B, Le Hellard S, Rietschel M, Lybaek H, Djurovic S, Mattheisen M, Muhleisen TW, Degenhardt F, Priebe L, Maier W, Breuer R, Schulze TG, Agartz I, Melle I, Hansen T, Bramham CR, Nothen MM, Stevens B, Werge T, Andreassen OA, Cichon S, Steen VM (2011) The complement control-related genes CSMD1 and CSMD2 associate to schizophrenia. Biol Psychiatry 70, 35-42.

[122] Cavanillas ML, Fernandez O, Comabella M, Alcina A, Fedetz M, Izquierdo G, Lucas M, Cenit MC, Arroyo R, Vandenbroeck K, Alloza I, Garcia-Barcina M, Antiguedad A, Leyva L, Gomez CL, Olascoaga J, Otaegui D, Blanco Y, Saiz A, Montalban X, Matesanz F, Urcelay E (2011) Replication of top markers of a genome-wide association study in multiple sclerosis in Spain. Genes Immun 12, 110115.

[123] Toomes C, Jackson A, Maguire K, Wood J, Gollin S, Ishwad C, Paterson I, Prime S, Parkinson K, Bell S, Woods G, Markham A, Oliver R, Woodward R, Sloan P, Dixon M, Read A, Thakker N (2003) The presence of multiple regions of homozygous deletion at the CSMD1 locus in oral squamous cell carcinoma question the role of CSMD1 in head and neck carcinogenesis. Genes Chromosomes Cancer 37, $132-140$.

[124] Ma C, Quesnelle KM, Sparano A, Rao S, Park MS, Cohen MA, Wang Y, Samanta M, Kumar MS, Aziz MU, Naylor TL, Weber BL, Fakharzadeh SS, Weinstein GS, Vachani A, Feldman MD, Brose MS (2009) Characterization CSMD1 in a large set of primary lung, head and neck, breast and skin cancer tissues. Cancer Biol Ther 8, 907-916.

[125] Kamal M, Shaaban AM, Zhang L, Walker C, Gray S, Thakker N, Toomes C, Speirs V, Bell SM (2010) Loss of CSMD1 expression is associated with high tumour grade and poor survival in invasive ductal breast carcinoma. Breast Cancer Res Treat 121, 555-563.

[126] Lehtokari VL, Pelin K, Herczegfalvi A, Karcagi V, Pouget $\mathrm{J}$, Franques J, Pellissier JF, Figarella-Branger D, von der Hagen M, Huebner A, Schoser B, Lochmuller H, Wallgren-Pettersson C (2011) Nemaline myopathy caused 
by mutations in the nebulin gene may present as a distal myopathy. Neuromuscul Disord 21, 556-562.

[127] Baranzini SE, Wang J, Gibson RA, Galwey N, Naegelin Y, Barkhof F, Radue EW, Lindberg RL, Uitdehaag BM, Johnson MR, Angelakopoulou A, Hall L, Richardson JC, Prinjha RK, Gass A, Geurts JJ, Kragt J, Sombekke M, Vrenken H, Qualley P, Lincoln RR, Gomez R, Caillier SJ, George MF, Mousavi H, Guerrero R, Okuda DT, Cree BA, Green AJ, Waubant E, Goodin DS, Pelletier D, Matthews PM, Hauser SL, Kappos L, Polman CH, Oksenberg JR (2009) Genome-wide association analysis of susceptibility and clinical phenotype in multiple sclerosis. Hum Mol Genet 18, 767-778.

[128] Verbeek EC, Bakker IM, Bevova MR, Bochdanovits Z, Rizzu P, Sondervan D, Willemsen G, de Geus EJ, Smit JH, Penninx BW, Boomsma DI, Hoogendijk WJ, Heutink P (2012) A fine-mapping study of 7 top scoring genes from a GWAS for major depressive disorder. PLoS One 7, e37384.

[129] Bruno AM, Huang JY, Bennett DA, Marr RA, Hastings ML, Stutzmann GE Altered ryanodine receptor expression in mild cognitive impairment and Alzheimer's disease. Neurobiol Aging 33, 1001 e1001-1006.

[130] McGregor L, Makela V, Darling SM, Vrontou S, Chalepakis G, Roberts C, Smart N, Rutland P, Prescott N, Hopkins J, Bentley E, Shaw A, Roberts E, Mueller R, Jadeja S, Philip N, Nelson J, Francannet C, Perez-Aytes A, Megarbane A, Kerr B, Wainwright B, Woolf AS, Winter RM, Scambler PJ (2003) Fraser syndrome and mouse blebbed phenotype caused by mutations in FRAS1/Fras1 encoding a putative extracellular matrix protein. Nat Genet 34, 203-208.

[131] Belmonte Mahon P, Pirooznia M, Goes FS, Seifuddin F, Steele J, Lee PH, Huang J, Hamshere ML, Depaulo JR Jr, Kelsoe JR, Rietschel M, Nothen M, Cichon S, Gurling H, Purcell S, Smoller JW, Craddock N, Schulze TG, McMahon FJ, Potash JB, Zandi PP Genome-wide association analysis of age at onset and psychotic symptoms in bipolar disorder. Am J Med Genet B Neuropsychiatr Genet 156B, 370-378.

[132] Knight HM, Pickard BS, Maclean A, Malloy MP, Soares DC, McRae AF, Condie A, White A, Hawkins W, McGhee K, van Beck M, MacIntyre DJ, Starr JM, Deary IJ, Visscher PM, Porteous DJ, Cannon RE, St Clair D, Muir WJ, Blackwood DH (2009) A cytogenetic abnormality and rare coding variants identify ABCA13 as a candidate gene in schizophrenia, bipolar disorder, and depression. Am J Hum Genet 85, 833-846.

[133] Machida T, Fujita T, Ooo ML, Ohira M, Isogai E, Mihara M, Hirato J, Tomotsune D, Hirata T, Fujimori M, Adachi W, Nakagawara A (2006) Increased expression of proapoptotic BMCC1, a novel gene with the BNIP2 and Cdc42GAP homology $(\mathrm{BCH})$ domain, is associated with favorable prognosis in human neuroblastomas. Oncogene 25, 1931-1942.

[134] Wang LL, Pan XL, Wang Y, Tang HD, Deng YL, Ren RJ, Xu W, Ma JF, Wang G, Chen SD A single nucleotide polymorphism in LRP2 is associated with susceptibility to Alzheimer's disease in the Chinese population. Clin Chim Acta 412, 268-270.

[135] Kantarci S, Al-Gazali L, Hill RS, Donnai D, Black GC, Bieth E, Chassaing N, Lacombe D, Devriendt K, Teebi A, Loscertales M, Robson C, Liu T, MacLaughlin DT, Noonan KM, Russell MK, Walsh CA, Donahoe PK, Pober BR (2007) Mutations in LRP2, which encodes the multiligand receptor megalin, cause Donnai-Barrow and facio-oculo-acousticorenal syndromes. Nat Genet 39, 957-959.

[136] Ishiguro H, Gong JP, Hall FS, Arinami T, Uhl GR (2008) Association of PTPRB gene polymorphism with drug addic- tion. Am J Med Genet B Neuropsychiatr Genet 147B 1167-1172.

[137] Barrett JH, Iles MM, Harland M, Taylor JC, Aitken JF, Andresen PA, Akslen LA, Armstrong BK, Avril MF, Azizi E, Bakker B, Bergman W, Bianchi-Scarra G, Bressac-de Paillerets B, Calista D, Cannon-Albright LA, Corda E, Cust AE, Debniak T, Duffy D, Dunning AM, Easton DF, Friedman E, Galan P, Ghiorzo P, Giles GG, Hansson J, Hocevar M, Hoiom V, Hopper JL, Ingvar C, Janssen B, Jenkins MA, Jonsson G, Kefford RF, Landi G, Landi MT, Lang J, Lubinski J, Mackie R, Malvehy J, Martin NG, Molven A, Montgomery GW, van Nieuwpoort FA, Novakovic S, Olsson H, Pastorino L, Puig S, Puig-Butille JA, RandersonMoor J, Snowden H, Tuominen R, Van Belle P, van der Stoep N, Whiteman DC, Zelenika D, Han J, Fang S, Lee JE, Wei Q, Lathrop GM, Gillanders EM, Brown KM, Goldstein AM, Kanetsky PA, Mann GJ, Macgregor S, Elder DE, Amos CI, Hayward NK, Gruis NA, Demenais F, Bishop JA, Bishop DT. Genome-wide association study identifies three new melanoma susceptibility loci. Nat Genet 43,1108 1113.

[138] Klimowicz AC, Bose P, Nakoneshny SC, Dean M, Huang L, Chandarana S, Magliocco AM, Wayne Matthews T, Brockton NT, Dort JC (2012) Basal Ki67 expression measured by digital image analysis is optimal for prognostication in oral squamous cell carcinoma. Eur J Cancer 48, 2166-2174.

[139] Djurovic S, Le Hellard S, Kahler AK, Jonsson EG, Agartz I, Steen VM, Hall H, Wang AG, Rasmussen HB, Melle I, Werge T, Andreassen OA (2009) Association of MCTP2 gene variants with schizophrenia in three independent samples of Scandinavian origin (SCOPE). Psychiatry Res 168, 256-258.

[140] Bashir R, Britton S, Strachan T, Keers S, Vafiadaki E, Lako M, Richard I, Marchand S, Bourg N, Argov Z, Sadeh M, Mahjneh I, Marconi G, Passos-Bueno MR, Moreira Ede S, Zatz M, Beckmann JS, Bushby K (1998) A gene related to Caenorhabditis elegans spermatogenesis factor fer- 1 is mutated in limb-girdle muscular dystrophy type $2 \mathrm{~B}$. Nat Genet 20, 37-42.

[141] Liu J, Aoki M, Illa I, Wu C, Fardeau M, Angelini C, Serrano C, Urtizberea JA, Hentati F, Hamida MB, Bohlega S, Culper EJ, Amato AA, Bossie K, Oeltjen J, Bejaoui K, McKennaYasek D, Hosler BA, Schurr E, Arahata K, de Jong PJ, Brown RH Jr (1998) Dysferlin, a novel skeletal muscle gene, is mutated in Miyoshi myopathy and limb girdle muscular dystrophy. Nat Genet 20, 31-36.

[142] Illa I, Serrano-Munuera C, Gallardo E, Lasa A, Rojas-Garcia R, Palmer J, Gallano P, Baiget M, Matsuda C, Brown RH (2001) Distal anterior compartment myopathy: A dysferlin mutation causing a new muscular dystrophy phenotype. Ann Neurol 49, 130-134.

[143] Schmidt WM, Uddin MH, Dysek S, Moser-Thier K, Pirker C, Hoger H, Ambros IM, Ambros PF, Berger W, Bittner RE (2011) DNA damage, somatic aneuploidy, and malignant sarcoma susceptibility in muscular dystrophies. PLoS Genet 7, e1002042.

[144] Aliev G, Obrenovich ME, Seyidova D, Rzayev NM, Aliyev AS, Raina AK, Lamanna JC, Smith MA, Perry G (2003) Xray contrast media induce aortic endothelial damage, which can be prevented with prior heparin treatment. J Submicrosc Cytol Pathol 35, 253-266.

[145] Overlack N, Kilic D, Bauss K, Marker T, Kremer H, van Wijk E, Wolfrum U (2011) Direct interaction of the Usher syndrome $1 \mathrm{G}$ protein SANS and myomegalin in the retina. Biochim Biophys Acta 1813, 1883-1892. 
[146] Reis CA, Campos D, Osorio H, Santos LL (2011) Glycopeptide microarray for autoantibody detection in cancer. Expert Rev Proteomics 8, 435-437.

[147] Swaminathan S, Kim S, Shen L, Risacher SL, Foroud T, Pankratz N, Potkin SG, Huentelman MJ, Craig DW, Weiner MW, Saykin AJ, The Alzheimer's Disease Neuroimaging, Initiative (2011) A genomic copy number analysis in Alzheimer's Disease and Mild Cognitive Impairment: An ADNI study. Int J Alzheimers Dis 2011, 729478.

[148] Havik B, Le Hellard S, Rietschel M, Lybaek H, Djurovic S, Mattheisen M, Muhleisen TW, Degenhardt F, Priebe L, Maier W, Breuer R, Schulze TG, Agartz I, Melle I, Hansen T, Bramham CR, Nothen MM, Stevens B, Werge T, Andreassen OA, Cichon S, Steen VM The complement control-related genes CSMD1 and CSMD2 associate to schizophrenia. Biol Psychiatry 70, 35-42.

[149] Cavanillas ML, Fernandez O, Comabella M, Alcina A, Fedetz M, Izquierdo G, Lucas M, Cenit MC, Arroyo R, Vandenbroeck K, Alloza I, Garcia-Barcina M, Antiguedad A, Leyva L, Gomez CL, Olascoaga J, Otaegui D, Blanco Y, Saiz A, Montalban X, Matesanz F, Urcelay E Replication of top markers of a genome-wide association study in multiple sclerosis in Spain. Genes Immun 12, 110-115.

[150] Kamal M, Shaaban AM, Zhang L, Walker C, Gray S, Thakker N, Toomes C, Speirs V, Bell SM Loss of CSMD1 expression is associated with high tumour grade and poor survival in invasive ductal breast carcinoma. Breast Cancer Res Treat 121, 555-563.

[151] Verbeek EC, Bakker IM, Bevova MR, Bochdanovits Z, Rizzu P, Sondervan D, Willemsen G, de Geus EJ, Smit JH, Penninx BW, Boomsma DI, Hoogendijk WJ, Heutink P. A fine-mapping study of 7 top scoring genes from a GWAS for major depressive disorder. PLoS One 7, e37384.

[152] Scharf JM, Yu D, Mathews CA, Neale BM, Stewart SE, Fagerness JA, Evans P, Gamazon E, Edlund CK, Service SK, Tikhomirov A, Osiecki L, Illmann C, Pluzhnikov A, Konkashbaev A, Davis LK, Han B, Crane J, Moorjani P, Crenshaw AT, Parkin MA, Reus VI, Lowe TL, Rangel-Lugo M, Chouinard S, Dion Y, Girard S, Cath DC, Smit JH, King RA, Fernandez TV, Leckman JF, Kidd KK, Kidd JR, Pakstis AJ, State MW, Herrera LD, Romero R, Fournier E, Sandor P, Barr CL, Phan N, Gross-Tsur V, Benarroch F, Pollak Y, Budman CL, Bruun RD, Erenberg G, Naarden AL, Lee PC, Weiss N, Kremeyer B, Berrio GB, Campbell DD, Cardona Silgado JC, Ochoa WC, Mesa Restrepo SC, Muller H, Valencia Duarte AV, Lyon GJ, Leppert M, Morgan J, Weiss R, Grados MA, Anderson K, Davarya S, Singer H, Walkup J, Jankovic J, Tischfield JA, Heiman GA, Gilbert DL, Hoekstra PJ, Robertson MM, Kurlan R, Liu C, Gibbs JR, Singleton A, Hardy J, Strengman E, Ophoff RA, Wagner M, Moessner R, Mirel DB, Posthuma D, Sabatti C, Eskin E, Conti DV, Knowles JA, Ruiz-Linares A, Rouleau GA, Purcell S, Heutink P, Oostra BA, McMahon WM, Freimer NB, Cox NJ, Pauls DL Genome-wide association study of Tourette's syndrome. Mol Psychiatry 18, 721-728.

[153] Benoit ME, Hernandez MX, Dinh ML, Benavente F, Vasquez O, Tenner AJ C1q-induced LRP1B and GPR6 proteins expressed early in Alzheimer disease mouse models, are essential for the C1q-mediated protection against amyloid-beta neurotoxicity. J Biol Chem 288, 654-665.

[154] Furney SJ, Simmons A, Breen G, Pedroso I, Lunnon K, Proitsi P, Hodges A, Powell J, Wahlund LO, Kloszewska I, Mecocci P, Soininen H, Tsolaki M, Vellas B, Spenger C, Lathrop M, Shen L, Kim S, Saykin AJ, Weiner MW, Lovestone S Genome-wide association with MRI atrophy measures as a quantitative trait locus for Alzheimer's disease. Mol Psychiatry 16, 1130-1138.

[155] Lesch KP, Timmesfeld N, Renner TJ, Halperin R, Roser C, Nguyen TT, Craig DW, Romanos J, Heine M, Meyer J, Freitag C, Warnke A, Romanos M, Schafer H, Walitza S, Reif A, Stephan DA, Jacob C (2008) Molecular genetics of adult ADHD: Converging evidence from genome-wide association and extended pedigree linkage studies. J Neural Transm 115, 1573-1585.

[156] Maydan G, Noyman I, Har-Zahav A, Neriah ZB, PasmanikChor M, Yeheskel A, Albin-Kaplanski A, Maya I, Magal N, Birk E, Simon AJ, Halevy A, Rechavi G, Shohat M, Straussberg R, Basel-Vanagaite L Multiple congenital anomalies-hypotonia-seizures syndrome is caused by a mutation in PIGN. J Med Genet 48, 383-389.

[157] Yang Y, Pan C Role of metabotropic glutamate receptor 7 in autism spectrum disorders: A pilot study. Life Sci 92, 149-153.

[158] Zhu X, Wang Y, Ogawa O, Lee HG, Raina AK, Siedlak SL, Harris PL, Fujioka H, Shimohama S, Tabaton M, Atwood CS, Petersen RB, Perry G, Smith MA (2004) Neuroprotective properties of Bcl-w in Alzheimer disease. J Neurochem 89, $1233-1240$

[159] Reynolds R, Hartnett ME, Atkinson JP, Giclas PC, Rosner B, Seddon JM (2009) Plasma complement components and activation fragments: Associations with age-related macular degeneration genotypes and phenotypes. Invest Ophthalmol Vis Sci 50, 5818-5827.

[160] Edvardson S, Cinnamon Y, Jalas C, Shaag A, Maayan C, Axelrod FB, Elpeleg O Hereditary sensory autonomic neuropathy caused by a mutation in dystonin. Ann Neurol 71, 569-572.

[161] Kushima I, Nakamura Y, Aleksic B, Ikeda M, Ito Y, Shiino T, Okochi T, Fukuo Y, Ujike H, Suzuki M, Inada T, Hashimoto R, Takeda M, Kaibuchi K, Iwata N, Ozaki N Resequencing and association analysis of the KALRN and EPHB1 genes and their contribution to schizophrenia susceptibility. Schizophr Bull 38, 552-560.

[162] Krug T, Manso H, Gouveia L, Sobral J, Xavier JM, Albergaria I, Gaspar G, Correia M, Viana-Baptista M, Simoes RM, Pinto AN, Taipa R, Ferreira C, Fontes JR, Silva MR, Gabriel JP, Matos I, Lopes G, Ferro JM, Vicente AM, Oliveira SA Kalirin: A novel genetic risk factor for ischemic stroke. Hum Genet 127, 513-523.

[163] Alvira-Botero X, Carro EM Clearance of amyloid-beta peptide across the choroid plexus in Alzheimer's disease. Curr Aging Sci 3, 219-229.

[164] Oules B, Del Prete D, Greco B, Zhang X, Lauritzen I, Sevalle J, Moreno S, Paterlini-Brechot P, Trebak M, Checler F, Benfenati F, Chami M (2012) Ryanodine receptor blockade reduces amyloid-beta load and memory impairments in Tg2576 mouse model of Alzheimer disease. J Neurosci 32, 11820-11834.

[165] Chakroborty S, Briggs C, Miller MB, Goussakov I, Schneider C, Kim J, Wicks J, Richardson JC, Conklin V, Cameransi BG, Stutzmann GE (2012) Stabilizing ER Ca2+ channel function as an early preventative strategy for Alzheimer's disease. PLoS One 7, e52056.

[166] Grupe A, Li Y, Rowland C, Nowotny P, Hinrichs AL, Smemo S, Kauwe JS, Maxwell TJ, Cherny S, Doil L, Tacey K, van Luchene R, Myers A, Wavrant-De Vrieze F, Kaleem M, Hollingworth P, Jehu L, Foy C, Archer N, Hamilton G, Holmans P, Morris CM, Catanese J, Sninsky J, White TJ, Powell J, Hardy J, O'Donovan M, Lovestone S, Jones L, Morris JC, Thal L, Owen M, Williams J, Goate A (2006) A scan 
of chromosome 10 identifies a novel locus showing strong association with late-onset Alzheimer disease. Am J Hum Genet 78, 78-88.

[167] Ghersi E, Vito P, Lopez P, Abdallah M, D'Adamio L (2004) The intracellular localization of amyloid beta protein precursor (AbetaPP) intracellular domain associated protein-1 (AIDA-1) is regulated by AbetaPP and alternative splicing. J Alzheimers Dis 6, 67-78.

[168] Daborg J, Andreasson U, Pekna M, Lautner R, Hanse E, Minthon L, Blennow K, Hansson O, Zetterberg H (2012) Cerebrospinal fluid levels of complement proteins C3, C4 and CR1 in Alzheimer's disease. J Neural Transm 119, 789797.

[169] Benoit ME, Hernandez MX, Dinh ML, Benavente F, Vasquez O, Tenner AJ (2013) C1q-induced LRP1B and
GPR6 proteins expressed early in Alzheimer disease mouse models, are essential for the C1q-mediated protection against amyloid-beta neurotoxicity. J Biol Chem 288, 654665.

[170] Jaeger S, Pietrzik CU (2008) Functional role of lipoprotein receptors in Alzheimer's disease. Curr Alzheimer Res 5, 1525.

[171] Kamboh MI, Barmada MM, Demirci FY, Minster RL, Carrasquillo MM, Pankratz VS, Younkin SG, Saykin AJ, Sweet RA, Feingold E, DeKosky ST, Lopez OL (2012) Genomewide association analysis of age-at-onset in Alzheimer's disease. Mol Psychiatry 17, 1340-1346.

[172] Youn H, Jeoung M, Koo Y, Ji H, Markesbery WR, Ji I, Ji TH (2007) Kalirin is under-expressed in Alzheimer's disease hippocampus. J Alzheimers Dis 11, 385-397. 